\title{
Sustainable value chain approach for livestock-based livelihood strategies for communities of the southeastern coast of Bangladesh
}

Sustainable value chain approach for livestock

\author{
Prabal Barua and Syed Hafizur Rahman \\ Department of Environmental Sciences, \\ Faculty of Mathematical and Physical Sciences, Jahangirnagar University, \\ Dhaka, Bangladesh, and \\ Maitri Barua \\ Chattogram Veterinary and Animal Sciences University, Chattogram, Bangladesh
}

\begin{abstract}
Purpose - The nature of farm animals in the marginalized group of people is varying hurriedly. Livestock is used to add to cash earnings and increase food security, hence helping as a vital component in the household's source of revenue strategies, particularly at marginal planter's level. The present study was conducted to assess the numbers of livestock farmers in the study areas, their livelihood options, the value chain of the farmers in different marketing channels and recommendation for the sustainable value chain of the livestock production cycle.

Design/methodology/approach - The study precise the baseline condition of marginal livestock farmers for access to value chain activities in terms of inputs, outputs, support services, production, yield, income and enabling environment to enhance livestock farming in the study area. The study was conducted through stratified random sampling of the context using some research tools like in-depth interviews, household surveys, expert opinions and focus group discussions. Structured questionnaires were developed to address issues, such as current livestock farming practices, access to support services, capacity and income.

Findings - The study revealed that this particular context is lagging behind to establish goat value chain activities in the targeted areas. The farmers do not have basic knowledge of goat farming, and the value chain actors are not working properly. The support services are not appropriate to turn the goat farming production to a standard level. Value chain of livestock and livestock products and their goals are essential to develop an idea on learning, investment, market access, sales assurance and quality. Variation in institutional contexts of end markets is linked to different types of coordination and control of enabling environment throughout the chains. Practical implications - Livestock is an integral component of the complex farming system in Bangladesh as it serves as not only a source of meat protein but also a major source of farm power services as well as employment. Strong private sector alliance along with public-private ventures can bring sustainable agriculture value chain development in these most vulnerable coastal communities in Bangladesh. Strengthening the weak financial structure, reducing power imbalances in the governance structures and low political intervention in community-level organizations, and resolving socio-cultural and environmental concerns are the major concerns on the development of value chains in Bangladesh.

Originality/value - Geographical position and climatic condition of Bangladesh have made her coastal areas one of the highly productive areas for livestock production in the world. The study was conducted through qualitative and quantitative analysis, and after finding the authors recommended for sustainable value chain approach for livestock production to a marketing channel for improving the financial condition and selfemployment for the communities.
\end{abstract}

Keywords Sustainability, Livestock, Value chain, Institutional context, South-eastern coast of Bangladesh Paper type Research paper

(C) Prabal Barua, Syed Hafizur Rahman and Maitri Barua. Published in Modern Supply Chain Research and Applications. Published by Emerald Publishing Limited. This article is published under the Creative Commons Attribution (CC BY 4.0) license. Anyone may reproduce, distribute, translate and create derivative works of this article (for both commercial and non-commercial purposes), subject to full attribution to the original publication and authors. The full terms of this license may be seen at http:// creativecommons.org/licences/by/4.0/legalcode
Received 2 August 2020

Revised 11 November 2020 2 December 2020

21 January 2021

Accepted 21 February 2021 
MSCRA

3,3

192

\section{Introduction}

The livestock sector has been playing a crucial role in the socio-economic development of Bangladesh. Livestock is an integral component of the complex farming system that not only serves as a source of meat protein but also is a major source of farm power services as well as employment. Altogether fisheries and livestock sub-sector contribute 35-40\% in the agriculture sector whose contribution is also $7-8 \%$ of the total GDP (Gross Domestic Production) and specifically $1.53 \%$ comes from animal husbandry. Almost $20 \%$ of the population of Bangladesh directly earns their livelihood through work associated with raising livestock production. Livestock resources also play an important role in the sustenance of poor marginalized landless people. The country has a relative density of livestock population well above the averages of many other countries of the world (MoFL, 2019). The GDP contribution of this sub-sector has been a modest 5.8\% annually in 2018 (Rahman et al., 2018) which was lower than the previous estimates of $5 \%$ of total and $10 \%$ of agricultural GDP during the 1990 and 1980s (Islam and Jabber, 2010).

Livestock resource plays an important role in the agricultural production sphere. About $1.60 \%$ of the national GDP is covered by the livestock sector in 2016-2017 fiscal years, and its annual rate of growth is $3.32 \%$. The livestock population in Bangladesh is currently estimated to comprise 23.935 million cattle, 1.478 million buffaloes, 25.931 million goats, 3.41 million sheep, 275.083 million chickens and 54.016 million ducks (DLS, 2019). Bangladesh country suffers from an acute shortage of livestock products like milk and eggs except for meat. The shortage accounts for 5.582 million MT for milk, and 2008.5 million number of eggs, whereas 0.019 million MT surplus of meat. Goat production is one of the major and important sectors in the Agricultural operation of Bangladesh (Hossain and Deb, 2016; Alam et al., 2017). Table 1 indicated the increasing rate of livestock production in Bangladesh over the 10 years (DLS, 2019), and Table 2 outlined the increasing contribution of Gross Domestic Production of Livestock production in the national economy of Bangladesh (DLS, 2019).

Goat has been renowned as a poor man's cow due to its immense contribution to the economy of a poor man. This not only supplies nutritious and easily digestible milk but also is a continuous source of additional income for poor and landless or marginal farmers. Goat rearing has been considered as a fundamental part of the different farming systems of Bangladesh. Goats are used to add to cash earning and boost food security, hence serving as a crucial constituent in household's livelihood strategies, specifically at marginal farmers' level. Being small-sized animals, goats can easily be managed by women and children. Feeding, milking and care of goats do not require much equipment and hard work. Capital investment and feeding costs are also quite low. The role of women in goat keeping is very significant in the rural families of Bangladesh and goat is the most important means through which rural women are able to contribute meaningfully to the cash needs of their family members. Moreover, goat rearing is the most useful way of women earning those who stay at home. There is a close relationship between the status of women and the socio-economic development of any country.

To ensure a balanced socio-economic development of the country, improving the status of women is a precondition. This may be achieved only when there is increased participation of women in development activities and goat rearing can be a good approach (Bhowmick et al., 2014; Hossain et al., 2015). The goat provides 50 million square feet of skin and skin obtained from the Black Bengal goats is of excellent quality. The export earnings from all leather and leather goods were $5.00 \%$ of the total export in 2012 (MoFL, 2019). The contribution of goatskin plays a significant role in this regard. Thus, goat farming plays an important and potential role in poverty reduction, income generation, contribution to food and nutrition security and employment generation.

A value chain can be comparatively straightforward, for instance in the case of the livestock value chain, where rural producers, intermediates and processors/packaging 
MSCRA

3,3

194

houses, and wholesalers and retailers are involved. A value chain can be extremely complex, for instance in the case of a passenger car or a personal computer, or in fact in footwear or garments, where producers in various countries across the globe work together. A whole value chain approach would encourage coordination of activities to mitigate climate risk and minimize the likelihood of maladaptation - that results when adaptation at precise nodes of a chain in turn compromises the concert of the value chain as a whole. This integrates inside and outside enterprise resources to meet the quick change of customers' needs and improves the competitive edge of the supply chain. The supply chain considers all business processes from point of origin to point of consumption, involving product $R \& D$, material procurement, manufacturing, marketing, logistics and after-sale services, etc (Lim-Camacho et al., 2015, 2016; Barua and Rahman, 2019; Lihua et al., 2019).

Power is often concentrated among one or a few chain participants that coordinate market activity. As the high-value product is based on consumer assurance, high standards for quality and safety, competitive price, and reliability of supply, lead actors in retail or export often coordinate the value chain members. Value chains are increasing and becoming more complex as required to grow all over the places. Moreover, consumers tend to demand for a higher quality goods which leads to a mass number of returns, translating directly to raised environmental effects. Thus, the urgent need to reduce those effects has aroused large attention from Governments, academia and industries. Many attempts are formulated to meet the trade-off among the environmental protection and cost reduced through various large economic entities. Long-term measures, such as product distribution and facility allocation, have more profound influences on the development of sustainable supply chain networks than short-term measures, such as power options and equipment transformation. The fact that more and more stakeholders realize the importance of long-term measures promotes in-depth study in this field. Since more attention has been put into this field, related studies have increased correspondingly (Govindan et al., 2018; Lufei et al., 2020).

The ability of smallholder farmers to take the lead is limited, as is their ability to maximize economies of scale. The market is also constantly changing, requiring rural farms and firms to respond and innovate by, for example, switching market channels, changing how they are organized, or investing in equipment. Such value chains may thus be less appropriate for many smallholder actors, who may lack the ability to handle dynamic markets and comply with their increasing amount of cultures, customs, regulations and standards. Local value chains that meet growing local demand might be more within the reach of smallholders. Local markets may also be characterized by new consumer demands due to changing lifestyles and increased knowledge of the benefits of more diversified products. Recently local value chain development has been advocated by environmentally conscious consumers demanding local farm products that they perceive as being of higher quality, leading to a rise in the number of specialty and local markets. Many producers have taken advantage of this trend by selling their produce at the growing number of local farmers' markets and/or directly to customers,

Table 2 . in GDP of Bangladesh Economy

\begin{tabular}{|c|c|c|c|c|c|c|c|c|c|c|}
\hline Issue & 2009-10 & 2010-11 & $2011-12$ & 2012-13 & 2013-14 & 2014-15 & $2015-2016$ & 2016-2017 & 2017-18 & 2018-19 \\
\hline $\begin{array}{l}\text { GDP } \\
\text { (base: } \\
\text { 2005-06) }\end{array}$ & 2.06 & 1.98 & 1.90 & 1.84 & 1.78 & 1.73 & 1.66 & 1.60 & 1.54 & 1.70 \\
\hline $\begin{array}{l}\text { Growth } \\
\text { rate of } \\
\text { GDP }\end{array}$ & 2.51 & 2.59 & 2.68 & 2.74 & 2.83 & 3.10 & 3.21 & 3.32 & 3.40 & 3.50 \\
\hline
\end{tabular}


thus creating local product value chains. One way to summarize a normal value chain (Figure 1) analysis process is to start at the end-market to find the most lucrative pro-poor value chains and then work backward through the value chain to reach the beneficiaries of the selected value chains, wherever they may be. The process is summarized below:

In Bangladesh, goat meat (chevon) is well accepted by the consumers irrespective of different communities and religious beliefs because of its easy utilization and unique taste. People of Bangladesh pay particular attention to this type of meat during wedding ceremonies and various other festivals. Goat production and marketing is one of the oldest and most widespread livestock enterprises in Bangladesh. The traditional marketing channel of their live goat is producer $\rightarrow$ middleman (trader) $\rightarrow$ butcher $\rightarrow$ consumer. At present, there is an increasing demand for quality and safe goat meat by consumers. To fulfill such demand of the consumers, it is a timely approach to study the goat value chain in Bangladesh with particular attention to their contribution as meat animals in Bangladesh economy. The goat value chain study will definitely enable the researchers and the policymakers to understand the contribution of actors involved in the production and marketing to determine future intervention strategies. It will also help determine the gap between demand for and supply of meat and will also give the insight to ensure food safety and quality meat production. As the smallholder farmers are the main actors in dominating the goat rearing, it is important to bring them into the value chain with a view to enhancing the economic condition by evolving all avenues of enterprise development and sustainable management of it. It would increase the food security of farmers by augmenting the available meat production in a sustainable manner. It would increase the food security of consumers as well as other actors involved in the value chain by enhancing/improving the meat production systems that are currently in practice and also by increasing their easy access to the goat meat market. Women perform the major activities of goat rearing. The development of sustainable enterprises through value chain analysis would empower women in the decision-making process and get rid of poverty and food insecurity conditions.

However, this process is not perfectly suited to VCA for this study due to the following reasons: (1) The beneficiaries of the study have already been selected, limited to specific areas; (2) They live in coastal areas, which due to infrastructural challenges and special institutional constraints mean that the identified end-market is often completely irrelevant to their current economic situation; (3) The selected value chain must be existing realities related which may not be the case if a normal VCA based on economic criteria alone is used. The process is summarized below (see Figure 2):

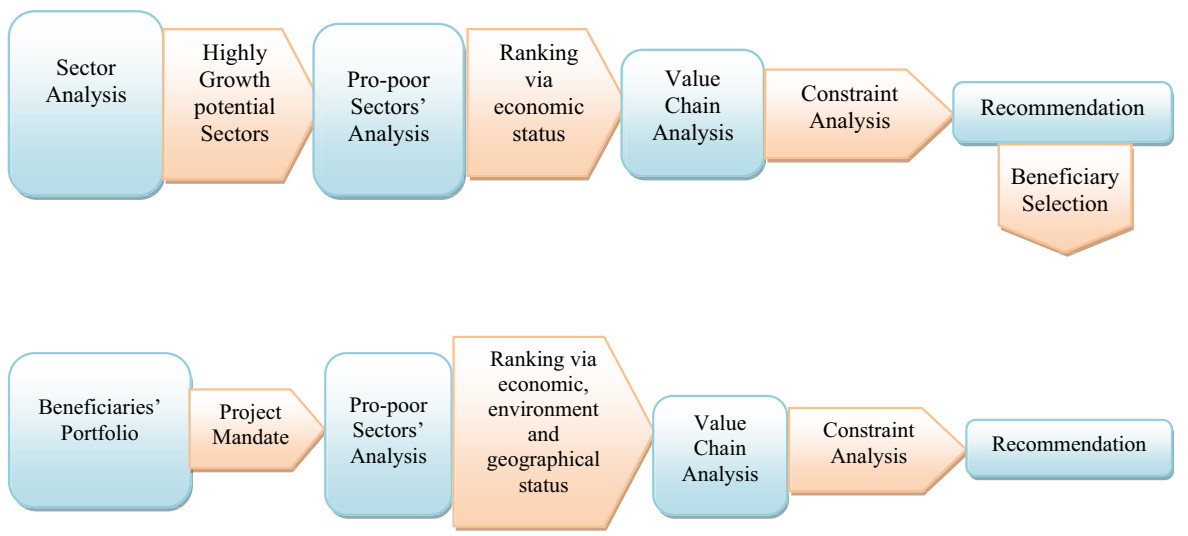

Sustainable value chain approach for livestock

195
Figure 1.

Normal value chain process

Figure 2.

Present study value chain process 
MSCRA

3,3

196

\section{Literature review}

Value Chain Analysis (VCA) is a diagnostic tool for supporting the process of continuous improvement at the level of the chain as a whole (rather than individual businesses). Taylor (2005) defines VCA as the multidimensional assessment of the performance of value chains through the examination of product flows, information flows and the management and control of the chain. Value chain analysis focuses on three key issues: first, the dynamics of information in the value chain from final consumption through to primary production and input suppliers and back again - how inclusive, transparent and responsive are the information flows in the chain; to what extent are stakeholders' decisions (what to produce, when to produce, how to produce) pulled by what consumers value? Second, the creation and flow of value, in the eyes of the final consumer, at each stage in the value chain - how many of the production and processing activities truly add value? How much investment is being made in these critical activities? How many are necessary but do not add value (these should be completed with minimal resource allocation)? How many are unnecessary (wasteful activities must be eliminated and resources re-allocated to drive value creation and efficiency)? Third, the nature of relationships - how much trust exists between different stakeholders? What is the nature of communication within and between organizations? What is the evidence of organizational commitment? How risks are shared and the assumption of risks rewarded in the chain. How the value created is shared along the chain? (Taylor, 2005; Bonney et al., 2007).

Dwivedi et al. (2019) proposed the sustainable manufacturing evaluation model for leather industries for India. He mentioned that because strict environmental regulations and ongoing government sustainable policies related to leather industries are largely affecting the challenges to conform themselves toward these sustainable policies. The major challenge faced by leather industries is the significantly rising value of adaptation options for sustainable products and progression. Moktadir et al. (2020) mentioned that interactive associations between the key performance indicators like Government support and trade policies, availability of raw materials, availability of skilled labor, technological capabilities, financial resources, improved process management, sustainable working environment, better labor health, improved labor safety, energy requirement, training and skill development, water supply, minimize hazardous materials, the adaption of environmental regulations and better waste management will help out the relevant stakeholders to fit in for successful sustainable supply chain policies in leather industries of India (Moktadir et al., 2020).

Moktadir et al. (2019) stated that Asian countries countenance the massive pressure from the universal market to pertain to environmental practice that tackles climate change to defending the environment. These countries are also practicing different green policies and practices such as green human resource management (GHRM), green supply chains, spherical economies, reverse logistics, corporate social responsibility (CSR) etc. Habitually, the responsibility for executing and supervising the above-mentioned policies and practices are increasing issues for the industrial sectors in perspective for developing countries economics for promoting sustainable value chain management for any industrial production as adopting green environment in all the activities.

Porter (1985) mentioned that the value chain originates from the concept of intra-linked and interrelated activities that are performed to support the products of a firm. He later added the concept of a multi-linked value chain which he referred to as the value system. The value system basically extended his idea of the value chain to include inter-linked linkages (Kaplinsky and Morris, 2000; Porter and Kramer, 2006). Another concept related to the value chain was that of the filiere that was used by French scholars to analyze the processes of vertical integration and contract manufacturing in French agriculture during the 1960s. The concept was initially developed to describe the flow of inputs and services in the production of a good while focusing on efficiency gains from economies of scale, transaction cost and 
transport cost. It was later applied in the French agriculture sector and later to the industrial sector in the 1980s (Kaplinsky and Morris, 2000).

The third concept that had been used from the mid-1990s is the global commodity chain which was also used to describe the value chain. This introduction ensured that significant progress was made in the use of the value chain concept because it focused on the power relations in the value chain analysis as well as on the governance issues such as the coordination of the production system thereby demonstrating that several value chains that could be described by a main or a lead party or parties who is responsible for upgrading within the value chain (Kaplinsky and Morris, 2000). Structures of governance in value chains according to Fearne et al. (2009) as three categories for effectiveness: (1) flow of information along the value chain for activity coordination, (2) the degree to which this information could be standardized and shared among agents and (3) the degree to which suppliers are capable of meeting the conditions placed upon them.

Goat value chains include all inputs and services that enable live goat production through transporting, processing and marketing of outputs, to the creation of added value products such as meat through consumption of the animal source foods and related products (Mohamadou, 2013). Goat value chain analysis made by Chowdhury et al. (2015) in Bangladesh and found the cost of production per kg is BDT 352.00 while the selling price is BDT 382.00 and the profit is only BDT 28.00 for farmers. It was observed that middleman's profit margin was higher for selling to butcher (BDT 228/US\$3) compared to traders (BDT 177/US\$ 2.3). Therefore, correct intervention particularly in husbandry practices would be needed in order to minimize the cost of production to maximize farmers' profit margin. At present no value-added products/processed meat are available from goats in the market.

Islam et al. (2009) found that most of the farmers $(80.5 \%)$ reared goats in semi-intensive systems in Bangladesh but few farmers $(7.3 \%)$ used confinement systems of rearing while $12.2 \%$ of farmers used free-range system. About $75.6 \%$ of farmers kept a goat at night in the goat house. In subsistence conditions, farmers rear $2-5$ goats with or without other large ruminants along with other agricultural operations or other non-agricultural professions. In this case, animals are reared by women and children. In the rural area, about $73.20 \%$ goat is reared under a low input production system (only natural grass and tree leaves) and the rest $(26.80 \%)$ are supported by the medium inputs (natural grass + some concentrate). About $6.20 \%, 8.10$ and $12.5 \%$ of goats of Bangladesh supported by medium inputs are reared in the subsistence, smallholder and small-scale-commercial operations, respectively (Islam et al., 2012). In recent times, the medium scale-semi intensive (20-25 does) and large intensive/semiintensive farms ( $\geq 100$ does) also gaining popularity due to demand and profit from goat farming and private entrepreneurs are coming forward to invest in this sector. In some urban and semi-urban areas, it is also observed some rooftop small-scale goat farms that gaining popularity.

Siddiky (2017) stated the marketing channel of Goat of Bangladesh which continues from the movement of a product or commodity from the site of production to the place of consumption. A large number of collectors, traders and butchers are associated with the live goat and goat meat business. Live goat and its meat marketing in Bangladesh are traditional and poorly organized like other agricultural products. The animals pass through different channels or middlemen before they reach to the butcher/retailer/consumers.

The most prominent channel of goat marketing is the movement of live goats from producers/farmers to the trader middlemen)/butchers in the village itself. The goat generally moves from the producers/farmers to traders/butchers in the weekly village bazaar. In the bazaar live goats to be sold are displayed by the owners and the primary traders purchase those individual basis. They sell their goats either to secondary traders (whole sale traders) or to the butchers at bigger markets. Secondly, traders mainly sell goats in flock to the city dealers or butchers.
Sustainable value chain approach for livestock 
MSCRA

3,3

198
Chowdhury et al. (2015) assess the socioeconomic analysis of goat farmers revealed that the average age of goat farmers was 42 with six years of schooling and 15 years' experience in goat rearing. Approximately $65 \%$ of the households are connected with goat farming either as a primary or secondary occupation. Farmers rear different breeds such as Black Bengal, Jamunapari and cross breeds. The Black Bengal occupies about $60 \%$ of the farm households. Each household of the study areas rears 11.8 goats on an average. Women are normally the goat farmers involved in production and marketing and playing an important role in decisionmaking of a family.

Sarker et al. (2014) conducted the mapping of goat supply chain shows that goats from the local areas are distributed all over the country. They found that a large number of collectors, traders and butchers are associated with live goat and goat meat business in the study areas. The value chain analysis indicates that farmers are normally selling their goats to the collectors and the customers of local market. The income generally varies depending on goat management procedure and the time of selling. Farmers' profitability data as developed by value chain analysis show that the cost of production per $\mathrm{kg}$ is BDT 352, the selling price is BDT 382 and the profit is BDT 28 . Therefore, correct intervention particularly in husbandry practices would be needed in order to minimize the cost of production to maximize farmers' profit margin.

\section{Problem statement and objective of the study}

Goat rearing practice in Bangladesh observing common problem for all farmers of study areas. Disease is the common problem for goat rearing and farmers losing huge losses while rearing goat died in front of their eyes. Goat treatment facilities improved in Bangladesh due to technological innovation but due to remote areas and natural calamities, treatment facilities not available for disease-affected goats. Besides, goat rearing practices and feeding of goats are not well enough for profitable activities. Besides, existing value chain approach of goat rearing and production process facing several problem and obstacles in the coastal area of Bangladesh.

The sustainability of the value chain can be expressed simultaneously along three dimensions: economic, social and environmental or triple bottom line (profit, people and planet) (Gebre and Rik, 2016). On the economic dimension, an existing or proposed upgraded value chain is considered sustainable if the required activities at the level of each actor or support provider are commercially profitable. On the social dimension, sustainability refers to socially acceptable outcomes in terms of the distribution of the benefits and costs associated with increased value creation. On the environmental dimension, sustainability is determined largely by the ability of value chain actors to show little or no negative impact on the natural environment from their value-adding activities; where possible, they should show a positive impact (Neven, 2014). This research seeks to address the following research objectives: (1) Mapping the value chain of goats in the study areas; (2) SWOT analysis of value chain of goat rearing and marketing and (3) Constraints analysis of goat value chain in responses to climate change in the study area. Hence, this paper is aimed at finding present status of literature on goat rearing practice in South-Eastern coast including value chain analysis with aimed at answering following research questions:

$R Q 1$. What are the socio-economic status of communities who are involving the goat rearing?

$R Q 2$. What are the practices of goat rearing is going on in the study areas by the coastal communities?

RQ3. What are the problems created for goat rearing in the study areas? 
RQ4. What are value chain actors and activities going on in the study areas for Goat production and marketing?

RQ5. What are the Strength, Weakness, Threat and Opportunities of sustainable goat rearing?

RQ6. What are main constraints for successful goat rearing practice?

RQ7. What are the sustainable approach of goat rearing in response of present vulnerability of climate change?

The present study primarily focuses on evaluating the baseline and potentials of local goat farmers in the study area through in-depth analysis of smallholder initiatives in local value chains that could give valuable insights on how to develop value chains based on local resources and context. The primary objective of the study was to assess the context and beneficiaries in terms of livelihood, capacity building and economic empowerment.

\section{Materials and methods}

\subsection{Study area}

Present study was carried out in Banskhali sub-district of Chattogram district because the areas was famous for cattle rearing and cattle production in the South-Eastern zone. The environmental conditions such as low lying water-filled grazing land, humidity, environmental temperature of this area are suitable for growth and survivable of livestock production. Banshkhali sub-district Upazila is located at $22.04851112^{\circ} \mathrm{N} 91.941616^{\circ} \mathrm{E}$ in Bangladesh. Its neighboring sub-districts are Anwara and Sangu to the north, Chakaria to the south, Lohagara and Satkania to the east, and Kutubdia and the Bay of Bengal to the west (Figure 3).

The study was concentrated for goat farmers in the area (Table 3) working with the beneficiaries addressing goat farming for their benefit in terms of livelihood, capacity building and economic return.

Even distribution and random sampling was conducted in these clusters to avoid biasness and to conceptualize existing realities of the whole targeted area in terms of current practices, shortcomings and income status.

\subsection{Approach of the study}

The study was designed to assess the existing status of the project targeted beneficiaries for the focus of creating a benchmark of the beneficiary's goat farming practices, capacity and income. In this connection, the dimensions of the whole contexts were evaluated. The approach (Figure 4) uses few tools to generate the data and information about the present prevailing practices.

The authors reviewed relevant literatures on goat farming projects, sector and subsector studies, policy documents, case studies that are relevant to the development of interventions in the selected regions. Literatures from different secondary sources like value chain reports, journals, government publications and newsletters on goat farming were studied to have a preliminary understanding of the production, technology, policies and market dynamics. Several key informants in-depth interviews were also conducted at this stage to make sense of the goat farming potential and the way of value chain development. The purpose of the indepth interviews was to gather facts and information on the goat farming to have a more qualitative overview of the sub-sectors.

\subsection{Data collection and analysis}

The collected data were analyzed by analytical and statistical tools. Analytical tools used were chain map, economic parameters (e.g. profit margin, gross margin and value share),
Sustainable value chain approach for livestock 
MSCRA

3,3

200

Figure 3.

Geographical location of the study area

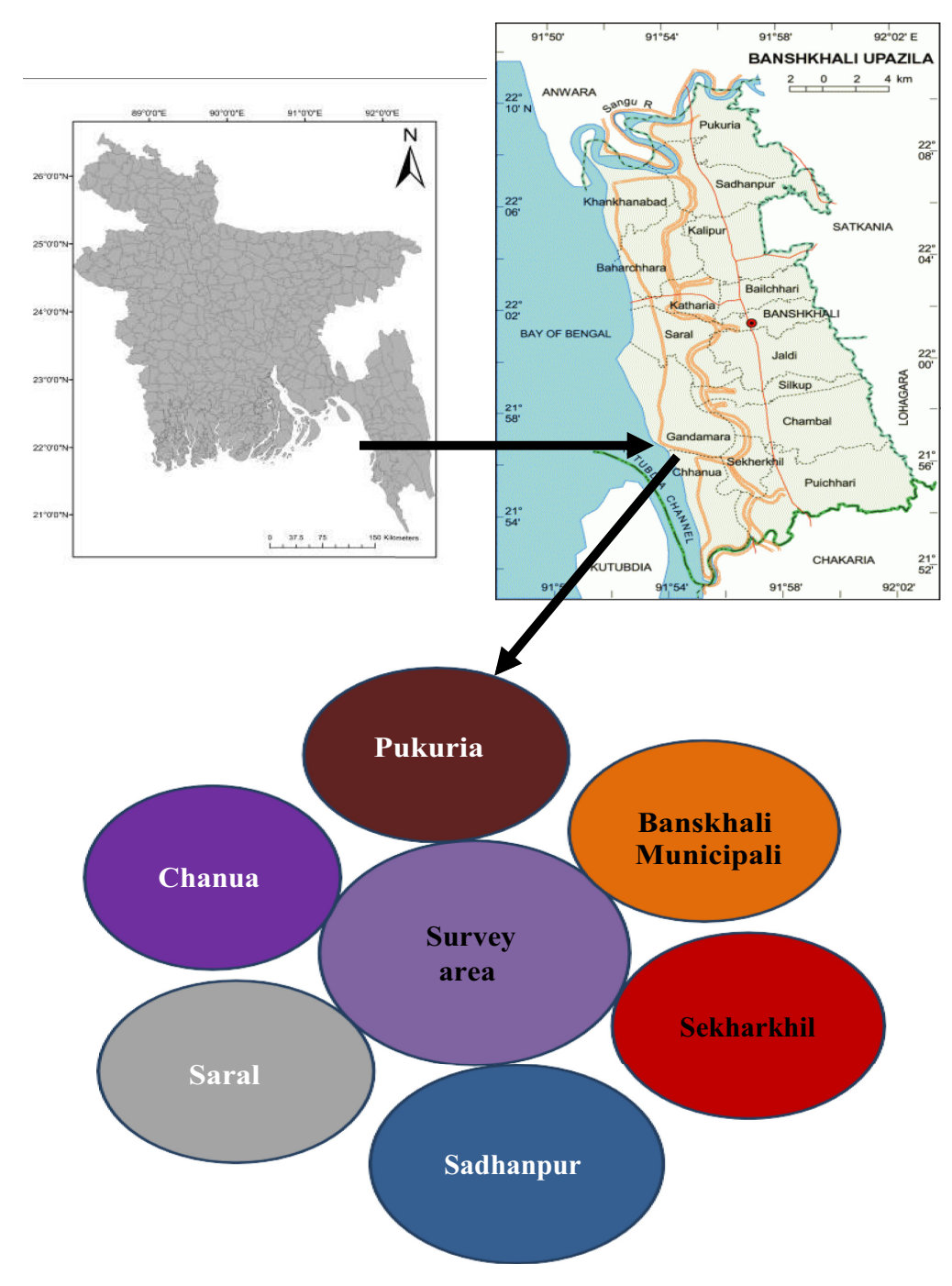

\begin{tabular}{lllll}
\hline District & $\begin{array}{l}\text { Sub } \\
\text { district }\end{array}$ & Existing union/Municipal & Sampled stations & Main market \\
\hline Chattogram & Banskhali & $\begin{array}{l}\text { Banskhali municipality, } \\
\text { Baharchara, Pukuria, Chanua, }\end{array}$ & $\begin{array}{l}\text { Banskhali municipality, } \\
\text { Pukuria, Saral, }\end{array}$ & $\begin{array}{l}\text { Banskhali } \\
\text { bazaar, }\end{array}$ \\
& & $\begin{array}{l}\text { Saral, Khankhanabad, } \\
\text { Gandamara, Sekherkhil, } \\
\text { Sadhanpur }\end{array}$ & $\begin{array}{l}\text { Sadhanpur, Baharchara } \\
\text { Sanigram }\end{array}$ & $\begin{array}{l}\text { bazaar, Chambol } \\
\text { bazar }\end{array}$ \\
& & & &
\end{tabular}

anpur
Table 3.

Geographic distribution of study area 


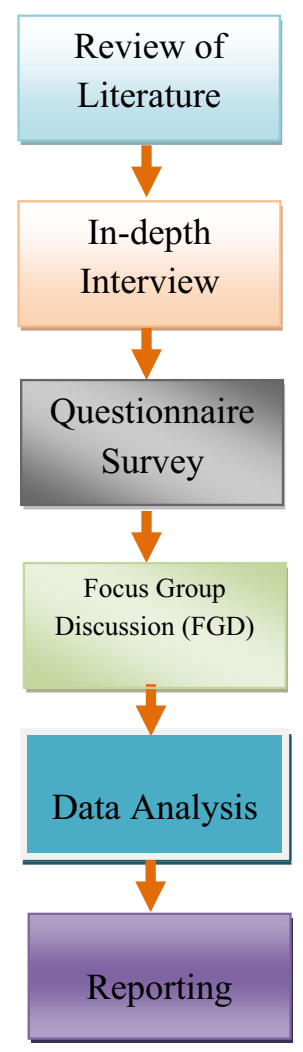



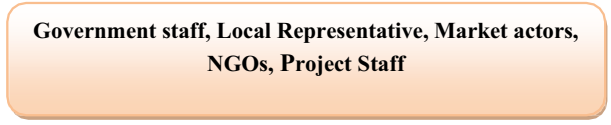

Goat producers and stakeholders

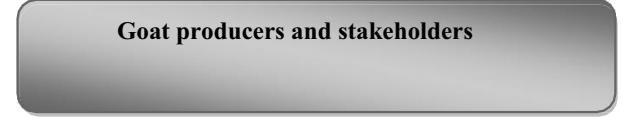

Beneficiaries and producers to validate the data and information collected through questionnaire surveys
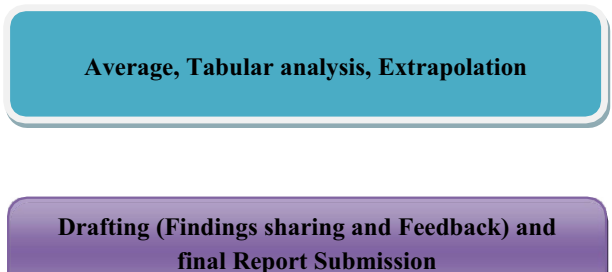
final Report Submission
Sustainable value chain approach for livestock

201

PESTEC (political, economic, social, technical/technological, environmental and cultural), and sustainability performance assessment. In order to have a visual representation of the whole chain in the study areas, chain mapping was employed with quantity and price at each actor level. Analysis specifying functions of each stakeholder across the chain was described under the map. Economic parameters like profit margin were used to analyze gross margin and added value share across the chain. PESTEC tool was used to analyses constraints and possibilities for smallholders' banana value chain in the district (see Table 4).

The analysis of the collected data included: practice, access to support service, income, value chain provisions and opportunities and constraints Analysis. An appropriate sample size can produce accuracy of results. Researchers followed a statistical formula to calculate the appropriate sample size.

The sample size were selected by the help of statistical representative formula (Islam, 2014) such as

$$
\text { Formula, } n_{0}=\left(\frac{z^{2} p q}{d^{2}}\right)
$$

where $n_{0}=$ desire sample size, $z=$ standard normal deviate usually set at 1.96 , which corresponds to the $95 \%$ confidence level $(z=1.96), p=$ assumes proportion in the target population estimated to have a particular characteristic $(p=0.5), q=$ proportion of the 


\begin{tabular}{|c|c|c|c|}
\hline $\begin{array}{l}\text { MSCRA } \\
3,3\end{array}$ & Questions & Details & Method or tool used \\
\hline \multirow[b]{3}{*}{202} & 1 & $\begin{array}{l}\text { What is the structure of existing goat value chain in } \\
\text { Banskhali sub-district of Chattogram, Bangladesh? }\end{array}$ & \multirow{4}{*}{$\begin{array}{l}\text { Literature review, survey, } \\
\text { interview, and group discussion } \\
\text { Survey, interview, and group } \\
\text { discussion } \\
\text { Survey, interview, and group } \\
\text { discussion } \\
\text { Survey, interview, and group } \\
\text { discussion }\end{array}$} \\
\hline & 1.1 & $\begin{array}{l}\text { What are the socio-economic status of communities who are } \\
\text { involving the goat rearing }\end{array}$ & \\
\hline & 1.2 & $\begin{array}{l}\text { What are the practices of goat rearing is going on in the } \\
\text { study areas by the coastal communities }\end{array}$ & \\
\hline \multirow{7}{*}{$\begin{array}{l}\text { Table } 4 \text {. } \\
\text { Summary of research } \\
\text { questions and data } \\
\text { collection methods are } \\
\text { indicated as follows }\end{array}$} & 1.3 & $\begin{array}{l}\text { What are the problems created for goat rearing in the study } \\
\text { areas? }\end{array}$ & \\
\hline & 1.4 & $\begin{array}{l}\text { What are key stakeholders (actors, partners and external } \\
\text { influencers) and their role in the chain? }\end{array}$ & $\begin{array}{l}\text { Survey, interview, and group } \\
\text { discussion }\end{array}$ \\
\hline & 1.5 & $\begin{array}{l}\text { What are the Strength, Weakness, Threat and } \\
\text { Opportunities of sustainable goat rearing }\end{array}$ & $\begin{array}{l}\text { Survey, interview, and group } \\
\text { discussion }\end{array}$ \\
\hline & 1.6 & $\begin{array}{l}\text { What are main constraints for successful goat rearing } \\
\text { practice? }\end{array}$ & $\begin{array}{l}\text { Survey, interview, and group } \\
\text { discussion }\end{array}$ \\
\hline & 1.7 & $\begin{array}{l}\text { What is sustainability performance of the goat value chain } \\
\text { looks like? }\end{array}$ & $\begin{array}{l}\text { Survey, interview, group } \\
\text { discussion, and observation }\end{array}$ \\
\hline & 1.8 & $\begin{array}{l}\text { What are the sustainable approach of goat rearing in } \\
\text { response of present vulnerability of climate change? }\end{array}$ & $\begin{array}{l}\text { Survey, interview, group } \\
\text { discussion, and observation }\end{array}$ \\
\hline & \multicolumn{3}{|c|}{ Source(s): Present Study } \\
\hline
\end{tabular}

estimation of population $(q=1-p), d=$ allowable maximum error in estimating a population proportion $(d=0.05)$.

Moreover, Simple Random sampling technique was adopted for successfully operating of 357 questionnaires at a household's level who are rearing the goat. Considering the representative sample size, the authors have distributed those samples on the statistical way with the help of following formula;

$$
\text { Random sampling, } \quad N j=\left(\frac{n}{N}\right) N i
$$

where, $N j=$ represents the sample size, $N=$ total population size, $(N=n i+n i i+n i i i$ $+\ldots \ldots+n n), N i=$ population size of study area, $n=$ desired sample size.

The collected data were analyzed through Value Chain Mapping and Opportunities and Constraints Analysis. The study relied more on secondary information which was collected from value chain actors like retailers, wholesalers and collectors required for the end market analysis (Singh and Mishra, 2013; Trienekens, 2011).

The value chain maps were developed to illustrate the channels through which the product flows from the conception stage to the production stage and finally to the end consumers through the traders. It identified the actors and support service providers, their roles and interactions within the value chain, and their performance. After mapping the selected value chains of different regions, the opportunities to include the target beneficiaries into the value chains while conserving the natural resources in the target geographic areas were identified. A comprehensive, cost benefit analysis has been done on each and every specific product in the selected value chains on specific sites under each of the regions. This cost benefit analysis revealed the strengths and weaknesses of every sub-sector to be worked on strategic opportunities.

On completion of data collection, filled-in questionnaires have been coded for computerization and edited for consistency. In the case of checking and editing of field data particular attention has been given to: (1) checking identification number of each respondent and (2) see whether the questionnaires have been properly filled in. The team 
deployed wide range facilities of hardware and software to deal with processing of survey data with speed and accuracy. Data input to computer included (1) developing appropriate computer program for data entry and (2) data entry operation.

The study involved both quantitative and qualitative variables. Measurement of the qualitative variables has been done in a manner that would facilitate maximizing the extent of internal consistency of the elements constituting each construct. In assessing the reliability and validity of each of the concepts involving multiple elements, multivariate statistical tools and other techniques have been deployed. To assess the overall distribution patterns of the responses and of the respondents' frequency tables, descriptive and inferential statistics have been used. Before that, appropriate dummy tables, providing framework for tabulation and analysis have been prepared.

\subsection{Analysis of sustainability indicators}

Sustainability indicators are particularly hard to define and measure. The basic problem is that sustainability is only occurs in the future while the indicators are measured in the present (USAID, 2012). Although the three sustainability dimensions (social, environmental, and economic) are treated individually here for clarity, in practice they overlap (USAID, 2012). Once the core processes of the value chain are mapped, indicators must be associated with each chain, for the three sustainability dimensions. The indicator selection depends on the level of the organization and the type of activities (Moreno and Salgado, 2012).

Moreover, many academic studies have assessed the sustainability of agri-food chains, but no agreement has been reached about the overall sustainability performance of local livestock crop system (Durham et al., 2009; Galli et al., 2015). Indeed, those assessments are challenging in their attempts to integrate livestock production and consumption within comprehensive decision-making tools. However, the scientific community has not yet agreed on a shared methodology which allows for robust and simultaneous comparisons over the sustainability dimensions of agri-food chains. Therefore, for this study, the selection of indicators was specifically adapted to the Bangladesh context concerning the goat sector in Chattogram district of Bangladesh. The assessment for each dimension was made based on the local situation in the study area. Performance assessment was used to measure selected sustainability indicators in the goat banana value chain. For this FAO assessment assesses (FAO, 2018) the impact of food and agriculture operations on the environment, economy and society. The assessment was done by a means of five qualitative score categories. For each of the selected indicators, a minimum threshold was defined $(1=$ for the unacceptable situations) and a maximum ( $5=$ the best situations). The reference points for the performance assessment were local realities in Bangladesh. This was done by researchers and other experts' judgment. For some indicators, the reference values were the results of the questionnaire. Then, the result obtained by each indicator has been converted into a score on a percentage scale.

\section{Results and discussions}

Geographical position and climatic condition of Bangladesh have made her coastal areas one of the highly productive areas of the world. About 20 million people live in the coastal region of Bangladesh; some are from the poorest and most marginalized groups in the country, 20 percent of them directly depend on the coastal and marine resources for their livelihood. They live exclusively on fishing and livestock farming and in the processing and marketing of agricultural products. The market for several of these products are promising, but the people involved early in the production chain, in livestock, fishing, primary processing and local trading, add little value and therefore can make a little profit (Barua et al., 2017).
Sustainable value chain approach for livestock 
MSCRA

3,3

\section{4}

Figure 5.

Cost (BDT) ranges

of livestock

Figure 6.

Family

household asset

Figure 7.

Land properties status

\subsection{Assets owned by the target beneficiaries}

From the study, it was found that, interviewed respondents are rearing livestock like, hen, duck, sheep, goat, cow and buffalo etc. So, The average value of livestock assets for the participant was BDT 51,741 (Figure 5).

However, the authors found that $23.25 \%$ of the households possessed the livestock asset range of BDT 60,001 to 120,000 whereas $15.97 \%$ participants own around BDT 30,001 to $60,000.13 .71 \%$ participants claimed they have BDT 6,001 to 9,000 amounts of livestock assets and only $9.8 \%$ beneficiaries own livestock asset above BDT 120,000.

From the study, it was found that respondent communities are basically poor and the study shows the average asset price of the participants is BDT 10,025 which is the cost of fridge, television, motor cycle, rickshaw, engine rickshaw, van, mechanized auto (CNG vehicle), jeep, bus, cell phone, microbus, truck, pick up etc (Figure 6). About one-fourth $(27.45 \%)$ of the respondents have materials for their daily uses cost below BDT 3,000 (Figure 6) whereas $22.69 \%$ mentioned they have materials costing BDT 3,001 to 6,000.

The authors assess that among the interviewed person, One-third (33.05\%) people of the context under study areas were landless (Figure 7). 19.89\% beneficiaries own land with an approximate value between BDT 0.2 to 0.4 million, $12.61 \%$ has land assets valued below BDT
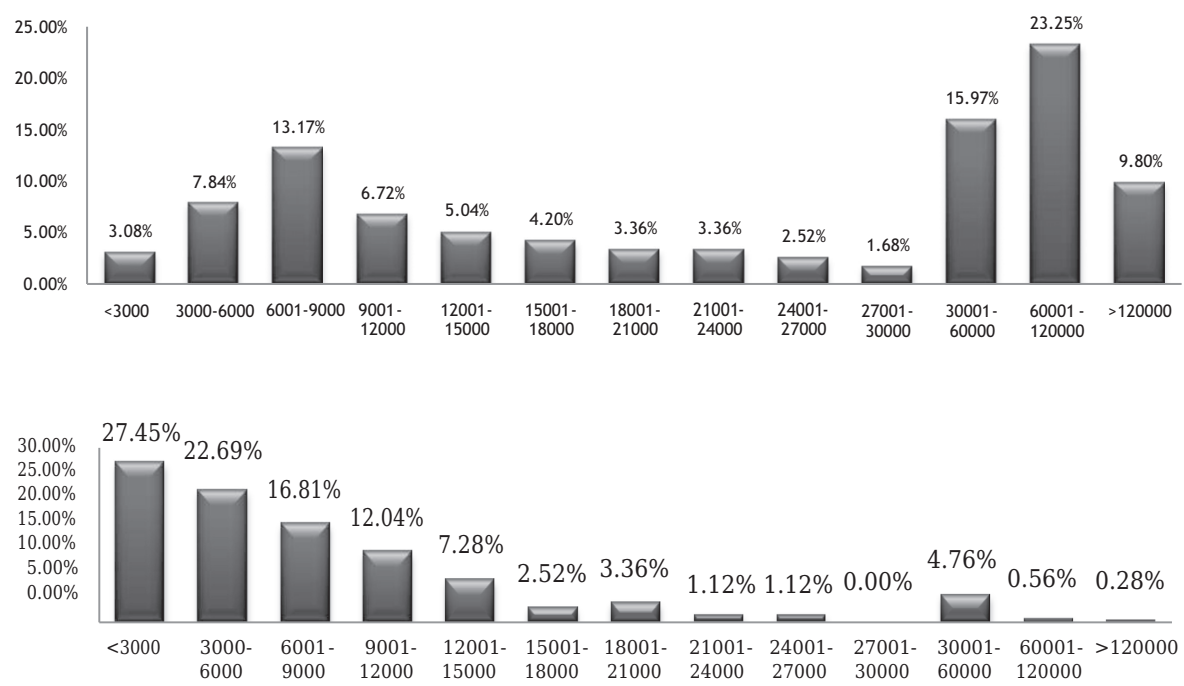

Asset ranges in BDT




0.2 million, $10.36 \%$ owns land asset which cost about BDT 0.44 to 0.6 million lac and only $5.88 \%$ respondents demanded their land asset value is above 1.5 million. It is to mention that there was a colony where there are landless peoples and government gave them land to reside.

During the study, the authors found 8 types of house found in the context but the respondents stated that almost $43.98 \%$ house are made of bamboo wall with roofing tin, $37.82 \%$ houses are tin walled with tin roofing and $5.6 \%$ mud wall roofing polythene and $4.2 \%$ are semi-pakka building, 2.8\% semi-pakka building with mud floor and same percentage was of bamboo wall roofing straw whereas only $2.24 \%$ households possess structured building houses.

In the context, different professions and livelihood strategies were recorded. The authors found the highest rate, $26 \%$ households lead their life from day laboring of the $\mathrm{HH}$ (Figure 8). $22 \%$ participants stated that their main income sourcing profession is agriculture, $20 \% \mathrm{HH}$ engaged in different services, $7 \%$ peoples deal with small-scale businesses in rural areas and $6 \% \mathrm{HHs}$ were found as rickshaw puller. $9 \%$ peoples mentioned about floating professions based on demand and season (see Figure 9).

From the study, the authors found that average monthly income of the households is BDT 11,042, the range is widely diverse (Figure 10). Among the respondents, $35.57 \%$ of the households have income of BDT 3,001 to 6,000 per month whereas $21.01 \%$ mentioned BDT 6,001 to $9,000,16.25 \%$ has BDT 9,001 to 12,000 and $9.52 \%$ of the households earn BDT 12,001 to 15,000 . Around $3.36 \%$ stated the range is from BDT 15,001 to $18,000,3.36 \%$ has BDT 18,001 to 21,000 and $2.80 \%$ has income of BDT 27,001 to 30,000 monthly. Around $5 \%$ has income between BDT 27001 to 60,000 . Very few $(0.59 \%)$ mentioned comparatively higher income of approximately BDT 100,000 monthly.

\subsection{Goat farming practices}

From the study, it was found that more than $60 \%$ of the households deploy minimum one member for goat rearing and they do it for the betterment of the household (Figure 10). Among the $36.97 \%$ of the families have two members, $2.24 \%$ farmers have three members and only $0.28 \%$ of the farmers have six or more than those members engaged in goat rearing in the studied area. Highest $22.69 \%$ families spend minimum four hours in goat rearing, whereas $17.65 \%$ spend three and five hours each, $15.69 \%$ spends minimum two hours and same percentage mentioned they spend almost six hours or more than that for goat rearing per day. $4.48 \%$ farmers give one hour time to manage their goat farming practice.

From the study, it was found that one-fourth of the interviewed communities are belong to ten or more then that year's goat rearing experiences which is a positive indicator for the

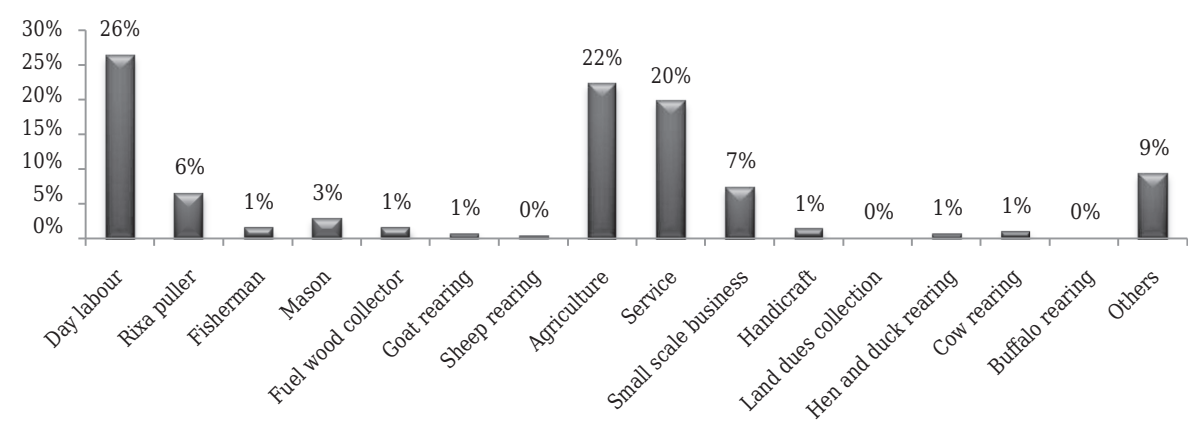

Profession
Sustainable value chain approach for livestock

205 
MSCRA

3,3

\section{6}

Figure 9.

Monthly income range status of the households

Figure 10.

Monthly income range status of the households
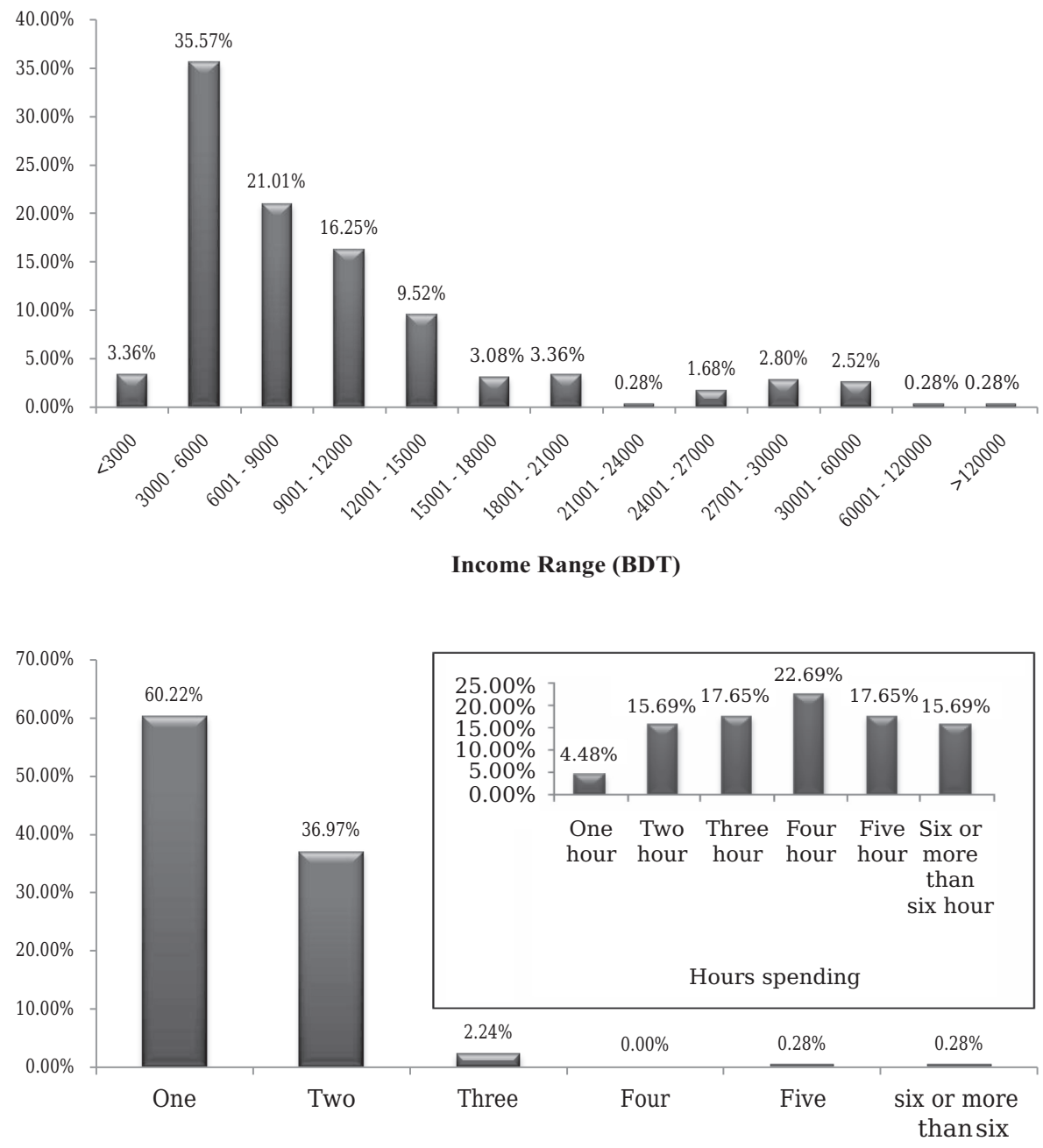

Number of family members engaged with goat rearing

research work and they will be able to cope with any developed technologies probably. $12.32 \%$ farmers bear two years goat rearing experiences whereas $12.04 \%$ has five years. $10.36 \%$ of the household has only one year experience of goat rearing and around $5 \%$ farmers are very new with the approach as they do not have any previous experiences in terms of rearing and management of goat farming. The authors assess that for the farming of goats the farmers collect yeanling from the following sources; $45 \%$ farmers have their own sourcing which is from their previous stocks, $13 \%$ mentioned about local supplier or hawker, $11 \%$ take lease from fellow farmers, $6 \%$ mentioned about private farm, $24 \%$ farmers are not fixed about the source and $2 \%$ farmers mentioned about multiple sources. Among the $100 \%$ participants of the study almost cent percent farmers belongs goats for rearing and business purpose. One-fourth of the participants $(24.93 \%)$ farmers have minimum one goat to rear and also almost one-fourth $(24.37 \%$ ) has two goats, $17.93 \%$ farmers have three, $11.48 \%$ has four, 
$8.40 \%$ has four goats, $4.48 \%$ has five and only around $5 \%$ farmers have more than six goats. The project has scopes to increase goat farmers in terms of number, yield and income.

The authors found that the context does not belong to any farmer who produces goat products. Even the farmers who possess more than two baby goats sometimes purchase milk from outside. In this regard, goat product means only meat. $80 \%$ farmers sell their products to local market and $17 \%$ farmers do it from their own premise to the hawkers or collectors. Project can design intervention regarding value-added products from goat rearing if the production is ensured. It was found that, $96.36 \%$ of the respondent households mentioned that they do not have access to goat medication facilities from government livestock offices (egg. veterinary) and only $3.64 \%$ farmers are able to avail these facilities. Project can take the lead to facilitate strong linkage between these two actors in value chain.

From the study, it was found that $90.5 \%$ of respondent stated that they do not have any training or technical knowledge about standard goat farming practices whereas $9.5 \%$ of respondents told that they have some technical acquaintance about goat farming. The project has a good scope to design intervention in this regard to boost up goat farming production in the targeted context through capacity building. on the other hand, $99.44 \%$ goat farmers mentioned about difficulties or no ease availability of buck services in their locality which is a re-requisite of goat farming. $0.56 \%$ farmers stated that they have availed this service easily.

Among the interviewees $70.03 \%$ told that they have input market access and they can buy feeds, medicines etc. from local markets. $29.97 \%$ farmers are still struggling to source their required goat farming inputs. Project should aim to facilitate linkage among the producers and input suppliers. Among the respondents, $69.19 \%$ of the interviewee claimed their access to local market for selling goat products easily whereas $30.81 \%$ farmers are not satisfied about existing marketing facilities.

\subsection{Common problems faced by the farmers}

During the study, the authors explored that $48.46 \%$ of the respondent told that disease of goat considered as main problem for goat rearing in the study areas, $14.29 \%$ of the respondent yet not faced any major issues whereas $10.64 \%$ stated the shelter place, grass fields or goat rearing place deficiency is a challenge for them. Around 3\% farmers thought feed is a problem as the formulated feed is costly, food shortage in rainy season and lack of fodder grasses. One-fourth $(23.25 \%$ ) of the farmers pointed multiple issues from the discussed points as their problem. Rural superstition was another minor issue which is still being considered as a problem in goat rearing.

From the study, it was found that $96 \%$ of the respondents stated about different sources of goat treatment whereas $4 \%$ farmers did not receive any facilitation of treatment for their goats. Among them $68 \%$ farmers took it from locally available doctors, $13 \%$ took from hospital, $12 \%$ mentioned about Kabiraj (local quack) and 3\% from other sources.

The participants were asked about the income generated from goat rearing in the last season. Currently, the average income per household is approximately BDT 6,320 yearly. But, the result indicated that $47 \%$ of the farmers " current income is below BDT 3,000 in last year. $18 \%$ farmers ranged from BDT 3,001 to 6,000. 12\% farmer said they earned between BDT 6,001 to 9,000 and $7 \%$ had the income of BDT 9,001 to 12,000 whereas $5 \%$ farmer mentioned it is BDT 12,001 to 15,000 . Only $2 \%-3 \%$ farmer had more than BDT 15,000 incomes from goat rearing last year.

\subsection{Overall family income apart from goat rearing}

The farmers have been asked to provide their household income of the last year apart from goat rearing to know the solvency. Among the respondents, $39.22 \%$ of the households stated the yearly income range of their family is between BDT 50,000 to $100,000.17 .93 \%$ of them
Sustainable value chain approach for livestock 
MSCRA

3,3

\section{8}

have it below BDT 50,000. Furthermore, 20.45\% farmers earn between BDT 100,000 to 150,000. $5.32 \%$ farmers earn between BDT 150,000 to 200,000 and approximately $7 \%$ household has income above BDT 200,000.

The respondents were asked about their thinking for goat farming in future. 100\% farmers of the context think goat rearing is a profitable business and they want to continue it. Motivation and demonstration from project end can make the goat farming business a sustainable one to change the fate of marginal farmers in the project area.

\subsection{Goat value chain actors and activities in the context}

Islam (2003) stated that the geographical location and the condition of climate of Bangladesh have made her coastal areas for highly productive region for agriculture production among the world. About 20 million coastal inhabitants of the Bangladesh representatives of the poorest and most marginalized groups in the country, $20 \% \mathrm{t}$ of them directly rely on the coastal and marine resources for maintaining their livelihood. They live exclusively on fishing, either as boat owners or as laborers, and in the processing and marketing of agricultural products.

The market for several of these products are promising, but the people involved early in the production chain, in fishing, primary processing and local trading, add little value and therefore can make a little profit. The low returns experienced by these groups are partly related to poor product quality and partly to lack of bargaining power in the marketing networks. In this study, the selected beneficiaries are experienced with some common resources which vary from location to location based on the suitability of the context. Barua and Rahman (2019) assess the sustainable value chain approach of agriculture products in response of climate change for south-eastern Bangladesh. They found some important candidates as marketable resources in the 4 sub-districts of Bangladesh. The marketable and non-marketable resources are listed below (Table 5).

The information gathered during the study enabled the longitudinal mapping of the goat value chain in the study area as presented in Figure 11 where the value chain map illustrates the way in which goat cattle and their products flow from production areas in the study areas to end markets and how the overall goat cattle sector operates. It is a visual representation of the structure of the value chain and its main characteristics or is a visual representation of the structure of the value chain and its main characteristics of climate change vulnerability. The marketing functions are represented on a vertical axis on the left hand side of the diagram and the existing actors are represented using boxes with solid outlines, which may encompass several vertically integrated functions.

The product and/or service flows between nodes are represented by arrows; for example, from production to wholesaling, from wholesaling to retail or export, or from primary wholesaling to secondary wholesaling (in the case of a series of port, or from The movement of a good or service between nodes implies that value is added to the product. The end market
Table 5.

List of marketable and non-marketable resources
Non-marketable resources

Poultry, honey, wheat, potato, cattle, shrimp, corn

Peanut, corn, jute, poultry, cattle, honey

Shrimp, poultry, honey, wheat, potato

Poultry, cattle, honey, jute, crab, corn 




Sustainable value chain approach for livestock

209

segments are placed at the top of the diagram and represented by ellipses. There are several channels, or end at the top of the diagram and represented by numerals at the top of the diagram and defined by product types, routes to market and end market segments. The number of actors in each segment, the flow volumes and profit margins constitute an important input to the value chain. While more quantitative data collection and analysis is ongoing to inform the process of value chain mapping, yet there are interesting findings emerging from the initial mapping that are worth discussing in this paper.

In traditional value chain of goat cattle's are strengthening programs, the value chains having good potentials and meeting with project mandates are selected and then beneficiaries are selected to match with the value chain requirements. Hence, while developing the preliminary list of value chains, we considered the commercial activities in which the community people (in which the target beneficiary lives) are currently engaged with, along with beneficiaries' resource, previous experience and expertise. That value chain which destructs forest and/or wetland directly will be ineligible for selection. Considering this fact, the authors had to eliminate the livestock related value chains like cattle rearing. Because, it was found out that the target geographic area suffers from natural fodder during the winter and summer. During this time, the community people either let their cattle and/or goat graze freely around or in the forest or they collect leaves from trees in the forest. Both these options are directly involved in the deterioration of forest resources.

The authors considered the commercial activities in which the community people (in which the target beneficiary lives) are currently engaged, along with beneficiaries' resource, previous experience and expertise. The potential issues from input to consumers of goats are presented resented in the Following Table 6.

Value chain is a chain of activities. Product pass through all activities of the chain in order and at each activity the product gains some value. Value chain analysis for goat crops are done to identify the actors involved in the supply chain of that commodity, to improve access of inputs, markets and services by mobilizing the small scale farmers and policy environment towards facilitation of the chain. Value chain generally starts with the raw materials supply at the farm level and ends with consumers who make the choice to buy, or not to buy, the finished product. Any value chain has several links between the farm and the consumer such as procurement, transportation, processing, commodity storage, conversion packaging, 


\section{MSCRA}

3,3

\section{0}

Table 6.

Goat value chain activities and actors

distribution, retailing and other services. Value chain analysis of goat in 01 years (two production cycles) is given in Figure 11.

From the finding of Figure 11, the average input cost is calculated on flock size of 11.80 goats during analysis of value chain. Value chain analysis reveals that generally farmers do not go for deforming and vaccination of their goat as needed. This may result even the death of the goat. Farmers have limited knowledge on feed, housing, medicine and overall disease management which reduces the goat yield and ultimately deprives them from good income. Farmers are normally selling their goat to the collectors and in local market as shown in the supply chain map. However, the farmers reared goat keeping in mind for marketing during Eid festivals. The income generally varies depending on the procedure of goat management, timing of selling. Good quality goat breed and buck/breeding services with subsidized rate from Govt. and NGOs could reduce the production cost, improvement of goat, income increment and facilitate farmers in empowering their capacity through training on improved production technology including housing, feed, disease management and other technologies. Initially making good quality goat breed, buck/breeding service and necessary natural feed availability could be useful intervention for protecting world famous Black Bengal goat and also in expanding commercial goat farming in Bangladesh.

\subsection{Scope for upgrading value chain}

5.6.1 Producers. Households are not capitalizing on their homestead plots by using them for goat farming, and even large farmers are not using proper farming techniques, thus not reaching the adequate level of productivity for goat in these areas. Literature review shows there is a yield gap in goat farming in marginal farmer levels which could be tackled through proper hands-on training and demonstration.

5.6.2 Input suppliers. The input suppliers have direct linkage with goat farmers and can potentially influence their behavior by marketing better quality inputs to them. They are also capable of promoting better goat farming techniques, by providing proper information about treatment of goats and using inputs properly. This has also been proven to be good incentive for input sellers to enhance the services of their business, resulting in more business. Farmers 
tend to build a closer relationship with input sellers who provide this embedded service and tend to purchase more inputs from them.

5.6.3 Traders. Bulk production of quality goats and goat products in these project regions would encourage more traders to become active in promoting their businesses. It will also provide the goat producers a basis for better bargaining.
Sustainable value chain approach for livestock

\subsection{Assessment of the regulatory services and support services}

5.7.1 Infrastructure. Among the studied areas it was found that those are easily accessible. Marketing and distribution channel could be smoothly established for the focus of promotion.

5.7.2 Public services. The level of satisfaction was found very low in terms of having access to public services like, training, medication and monitoring from DLS.

5.7.3 Financial services. Microcredit organizations are found very low in supporting the current project mandate, i.e. goat farming. Farmers are not having easy access to finance.

\subsection{Youth, poor people and gender participation}

A promising goat farming sector in these regions can ensure the participation of youth and poor marginal income group of peoples in this business. The activities related to goat farming are strongly significant from household point of view. Woman can easily take lead of the feeding, monitoring and rearing of goats. Thus, the project can also address gender as crosscutting issue. The questionnaire interviews revealed that women and youth participation in these project areas is promising. Proper practices of goat farming can check the issue of "unpaid labor" of women as they can keep money to spend for their own discretion.

\subsection{SWOT analysis for the goat rearing of study area}

In the study areas, there are different types of input suppliers who are active and catering to the different kinds of goat farmers - commercial ones and marginal farmers, for different kinds of needs. Increased homestead cultivation of goat in the study areas will increase consumption of meat of the producers' households. Increased supply from small-scale producers will also add to more goats being sold at the local haats and also make it more accessible for marginal households to purchase them. The SWOT analysis of livestock especially goat sector values chain is expressed in the following Table 7.

\subsection{Constraints analysis for goat farming}

The goat farmers in the study areas face a number of constraints in different phases of farming. As most of the goat reared in the rural area and goat mainly depends on natural pasture, the main constraint that faces the framers is lack of available natural pasture and scarcity of land for fodder cultivation. Seasonal fluctuation and availability of feed also affect goat farming. Beside these, some other major constrains listed below that affect sustainable and commercial goat farming in Bangladesh which are listed below in Table 8. One of the key constraints in designing any intervention in the agribusiness sector is the lack of sufficient and authentic information on the size of the enterprises and values generated. The process will provide deep understanding of constraints and interventions in goat sub-sector. Constraints need to be prioritized based on importance and immediate demand according to Table 8.

\subsection{Sustainable value chain approach}

Sustainable Value Chain Analysis (SVCA) incorporates both Value Chain Analysis (VCA) and Life Cycle Analysis (LCA) to determine the value that final consumers attach to the activities that contribute to emissions and the impact on consumer perceptions of value of 
MSCRA 3,3

\section{2}

Table 7.

SWOT Analysis of the study area for goat rearing
Strength

(1) Available natural food for goat/not dependent on formulated feed

(2) Little human effort needed, approximately $60.22 \%$ families have only one person handling the goats

(3) Goat farming is a good practice here, $24.37 \%$ families rearing goats more than ten years

(4) Yeanling production from home, $45 \%$ families produce yeanlings from their own home

(5) Hundred percent families are interested to continue the goat rearing
Opportunities

(1) Goat can be reared integrating with other domestic animals

(2) Approximately $70 \%$ families have the basic input (feed, medicine and others) service from their local market

(3) Approximately $68 \%$ families take the treatment for their goat from local doctor

(4) Market access for selling their goats, $80 \%$ families sells their goats to the nearest local market

(5) Woman can take the lead
Weakness

(1) Insufficient training on goat rearing, 90.5\% families does not have any academic training on goat rearing

(2) Insufficient govt. Medical services, 96.36\% families do not take the govt. Medical services

(3) Do not have the access to the thane agricultural fair. No fair arrangement was recorded

(4) Do not use slate technology

(5) Do not have any knowledge about hydroponic feed production

(6) No association or farmers' group or cooperative is available

(7) Do not have any access to the microcredit loan

(8) Do not have any knowledge about goat development policy and feed act of Bangladesh

(9) Do not have the access to the vaccine camp. $98.60 \%$ families do not have this access

(10) Rearing space shortage
Threats

(1) Do not have the proper buck service. 99\% families are not satisfied for this service/ suffering for this service

(2) Disease problem hampers the goat rearing tremendously

(3) Wild animals (particularly dog) most often attacks on goat

(4) Goat death leads to asset loss hence unwilling or unable to continue goat farming

changes to production processes and product attributes. As this method includes the environmental impact assessment (in this example $\mathrm{CO} 2$ emissions) at all stages in a value chain, in conjunction with the activities, materials and operations, it is able to facilitate more effective resource allocation by identifying priority areas and bottlenecks. Measuring environmental impacts such as carbon emissions in a value chain, in isolation, is of limited value and potentially damaging to the competitiveness of a value chain, if consideration is not given to the value that final consumers attach to the activities that contribute to emissions (de Bakker and Nijhof, 2002).

Sustainability of the goat value chain was assessed through selected indicators related to the local level in the study areas. The discussion was made with experts on selected sustainability performance indicators of the goat cattle value chain with reference to the Bangladesh situation. Accordingly, the authors put judgment ranged from unacceptable to best (1-5) for the selected indicators. The result obtained by each indicator has been converted into a percentage scale. As it is shown in Table 7, there are 8 indicators under economic dimension. Thus, the maximum potential score for the economic dimension was 8 indicators $\times 5$ points (best/dark green) $=40$. However, the actual ratings for the economic indicators were 1 dark green $(1 \times 5), 3$ light yellow $(3 \times 3), 1$ dark yellow $(1 \times 2)$ and 3 red $(3 \times 1)=19$. The actual total score by the maximum total score $(19 / 40)=0.475$. The final score for the economic dimension was $19 / 40=47.5 \%$. This is between 40 and 60 percent, 


\begin{tabular}{ll}
\hline Actors & Functions \\
\hline Input suppliers & $\begin{array}{l}\text { Selling seeds, feeds, fertilizers to the } \\
\text { producers }\end{array}$
\end{tabular}

Public livestock services

Providing information to farmers about farming techniques

Private livestock services

Farmers/

Producers

Financial services

Rural farias

Collecting from producers and selling to Aratdars

Arats (or arotdars)

Rural retailers

Retailing meats to local consumers

Local Consumption of meats and milk consumers

Providing information to farmers about farming techniques and proper usage of inputs

Produce goats and products

Providing finances to producers to be used for cultivation of goats

Wholesale facilitation of goats at the main markets (bazaars)
Constraints

They do not source high quality seeds/yeanling since the demand for them is low. Also, they are not able to provide the proper information about how these inputs should be used to ensure best productivity

The public extension service is not actively operating in most of the project areas. Thus, farmers are not getting the required information about treating diseases and using proper farming techniques to ensure high productivity. This results in farmers not being able to produce high yield and not making much profit from it

The demand for inputs is very low in this area, so private companies are not active in these regions. They are also not aware of the potential to farm goats by using modern facilities, slate technology, quality feeds, hydroponic grass production etc. Farmers are currently not aware of how best to use high quality inputs to get the best production from their practices. For marginal farmers, the additional cost of using better inputs is perceived as unnecessary since they are not aware of the value addition from higher productivity

Farmers are not aware about the potential and profitability of goat farming sector. Currently, they are not well-informed about the techniques and provisions in goat farming

Using better inputs for goat farming will result in some increase in the cost of production. Marginal farmers would be inclined to get microcredit products for investment into goat farming. But, microcredit institutions do not provide loan or supports that can be repaid at the end of a production cycle of a goat

Farias are only active for sourcing goats and goat products where there is a high production. Even then, most of these regions have very few farias which could be addressed if there is a bulk production

Mainly buying from producers and farias to be able to sell large quantities. They sell to local retailers and/or consumers. This actor is not established in project target areas

These retailers buy the goats from the arotdars or beparis of local producers, and sell them mainly to local households

Consumption of meat and milk is low in these regions, since supply is low and prices are high. Most producers can meet their household milk requirements from their own goat farming
Sustainable value chain approach for livestock
Table 8.

Constraints Analysis for goat farming value chain 
MSCRA

3,3

214

which corresponds to light yellow rating or moderate performance. The maximum potential score for the social dimension was 12 indicators $\times 5$ points $=60$. The actual ratings of social indicators were 2 light green $(2 \times 4), 3$ light yellow $(3 \times 3), 2$ dark yellow $(2 \times 2)$ and 3 red $(3 \times 1)=28$. Dividing actual total score by maximum total score $(28 / 60)=0.466$. The final score of the social dimension was $46.67 \%$. This is between 40 and 60 percent, which corresponds to light yellow rating or moderate performance. The maximum potential score for Economic dimension was 5 indicators $\times 5$ points $=25$. The actual ratings of environmental indicators were 1 light green $(1 \times 4)$, 1 light yellow $(1 \times 3)$, 2 dark yellow $(2 \times 2)$ and 1 red $(1 \times 1)=12$. The final score of the environmental dimension was $12 /$ $25=0.48$ or $48 \%$, which is between 40 and $60 \%$ of the performance score or moderate performance. Therefore, the sustainability performance of the goat cattle value chain related to economic, social and environmental dimensions is as in Table 9 (see Table 10).

Due to a lack of awareness to join cooperatives as well as immediate payment and credit dependency; most of the goat producers sold to traveling traders rather than selling through cooperatives. Wholesalers set the prices and there by influenced the prices of retailers, traveling traders' goat cooperatives and producers. Wholesalers networked with wholesalers in other areas so that they dominated the governance of the goat cattle value chain. They exchanged information on goat prices, local supply situation and the prospects of production in their area. The relationship among traders existed with a verbal agreement and high trust. The smallholder farmers were not organized enough to govern the value chain. There was a weak relationship between the goat cattle marketing cooperatives. Each cooperative only had a relationship with traders in their respective market channels.

The potential interventions are detailed below, considering the opportunities that can be worked on with specific actors to improve goat cultivation in these areas for sustainable value chain approach of goat farming in the study areas. These intervention will helpful for coastal communities in response to climate change induced socio-economic problem in future (Table 11).

\section{Conclusions and recommendation}

The Poverty of coastal communities observed in assorted scope in the civilization along with the genesis as per capita income, relative place in society, etc. All experiential confirmation recommended that it's a glitch of the society. It has been defended that no super smack is available for sustainable solutions. But, the authors apparently and inferentially recommended for the implementation of "Value Chain Sustainability" considerably contributed to the solution of this community problem through the transfer or mitigation of poverty from one dimension to another approach. The aim to study, to calculate the contribution of value chain sustainability for the eradication of poverty and adaptation of climate change has been staggered on the noteworthy confirmation in favor to object through enthusiastic methodology in particular sample areas.

Generally, management of value chain approaches requires firms to work jointly to advance coordinated and approachable value-driven processes and approaches, and to put forth a widespread effort in sustainable solutions of the market or supply chain problems (Bonney et al.,2007). A sustainable value chain approach in response to climate change effects may therefore existing occasions for production firms to administer the climate change risk issue by implementing community-based adaptation options for profitable livestock productions that may be more preferred or conventional by consumers crossways the whole value chain.

Variation of institutional contexts of end markets is linked to different types of coordination and control of enabling environment throughout the chains. Local and national networks enhance the value chain in terms of value addition, technology enhancements, 


\begin{tabular}{|c|c|c|c|c|c|}
\hline Issue & Indicators & Chain performance & $\begin{array}{l}\text { Judgment } \\
\text { scale }\end{array}$ & $\begin{array}{l}\text { Performance } \\
\text { score }\end{array}$ & $\begin{array}{l}\text { Sustainable } \\
\text { value chain }\end{array}$ \\
\hline \multirow[t]{8}{*}{ Economic } & Profitability & $\begin{array}{l}\text { Revenue earned from goat sales exceeded } \\
\text { production and marketing costs for farmers } \\
\text { and traders }\end{array}$ & 5 & $80-100 \%$ & $\begin{array}{r}\text { approach for } \\
\text { livestock }\end{array}$ \\
\hline & Added value shares & $\begin{array}{l}30 \% \text { of the added value was shared by } \\
\text { wholesalers while } 26.56 \text { and } 15 \% \text { were } \\
\text { shared by farmers and traveling trades }\end{array}$ & 3 & $40-60 \%$ & 215 \\
\hline & Chain governance & $\begin{array}{l}\text { Wholesaler set prices without negotiation } \\
\text { with farmers }\end{array}$ & 1 & $0-20 \%$ & \\
\hline & Faire trade & $\begin{array}{l}\text { Traders were not paid a fair price for } \\
\text { farmers }\end{array}$ & 1 & $0-20 \%$ & \\
\hline & Diversity of market & $\begin{array}{l}\text { Less effort was made to access alternative } \\
\text { market channels, in case, relationship with } \\
\text { existing traders are discontinued }\end{array}$ & 3 & $40-60 \%$ & \\
\hline & Productivity & $\begin{array}{l}\text { Goat productivity was less than potentials } \\
\text { of the area and not adapted to } \\
\text { environmental shocks } \\
\text { According to experts from livestock } \\
\text { department the production potential of the } \\
\text { goat is } 300 \text { quintal per hectare }\end{array}$ & 3 & $40-60 \%$ & \\
\hline & Value-adding activities & $\begin{array}{l}\text { Only sorting and labeling was done by } \\
\text { retailers. There were no processing } \\
\text { activities for goat cattles }\end{array}$ & 2 & $20-40 \%$ & \\
\hline & Product loss & $\begin{array}{l}\text { High loss of product due to postharvest } \\
\text { handling and logistic problems }\end{array}$ & 1 & $0-20 \%$ & \\
\hline \multirow[t]{12}{*}{ Social } & Employment & Created job opportunities for youths & 4 & $60-80 \%$ & \\
\hline & Labor condition & No child labor & 4 & $60-80 \%$ & \\
\hline & Gender & $\begin{array}{l}\text { No gender equality in goat production and } \\
\text { marketing. At the farm level, men were } \\
\text { engaged in both production and marketing } \\
\text { while at retailer level women was engaged in } \\
\text { marketing }\end{array}$ & 2 & $20-40 \%$ & \\
\hline & Transportation & $\begin{array}{l}\text { Transported by open vehicles for long- } \\
\text { distance }\end{array}$ & 1 & $0-20 \%$ & \\
\hline & Road & $\begin{array}{l}\text { The road from farm gate to the distributor } \\
\text { was not uniformly distributed for goat } \\
\text { transportation }\end{array}$ & 2 & $20-40 \%$ & \\
\hline & Market information & $\begin{array}{l}100 \% \text { of the market information was in } \\
\text { hands of traders }\end{array}$ & 1 & $0-20 \%$ & \\
\hline & Product information & $\begin{array}{l}\text { There was no complete and accessible } \\
\text { information on product quality and safety } \\
\text { for consumers }\end{array}$ & 1 & $0-20 \%$ & \\
\hline & $\begin{array}{l}\text { Stakeholders } \\
\text { relationship }\end{array}$ & $\begin{array}{l}\text { There was a good relationship between } \\
\text { farmers, input suppliers, supporters, and } \\
\text { influencers. The relationship between } \\
\text { farmers and traders was trust-based }\end{array}$ & 3 & $40-60 \%$ & \\
\hline & Safety and hygiene & $\begin{array}{l}\text { Goat waste released at loading, unloading } \\
\text { and marketing area. It affects the health of } \\
\text { people in the market }\end{array}$ & 2 & $20-40 \%$ & \\
\hline & Product quality & $\begin{array}{l}\text { Low goat product quality due to careless } \\
\text { handling and logistic problem }\end{array}$ & 3 & $40-60 \%$ & \\
\hline & Farming method & $\begin{array}{l}72 \% \text { of farmers used mono-cropping } \\
\text { method }\end{array}$ & 2 & $20-40 \%$ & \\
\hline & $\begin{array}{l}\text { Farmers' cooperation } \\
\text { for bargaining power }\end{array}$ & $\begin{array}{l}\text { Cooperative members have relatively higher } \\
\text { bargaining power than private farmers for } \\
\text { the goat price }\end{array}$ & 3 & (continued) & $\begin{array}{r}\text { Table } 9 . \\
\text { Suitability assessment } \\
\text { of goat value chain in } \\
\text { the Study Areas }\end{array}$ \\
\hline
\end{tabular}




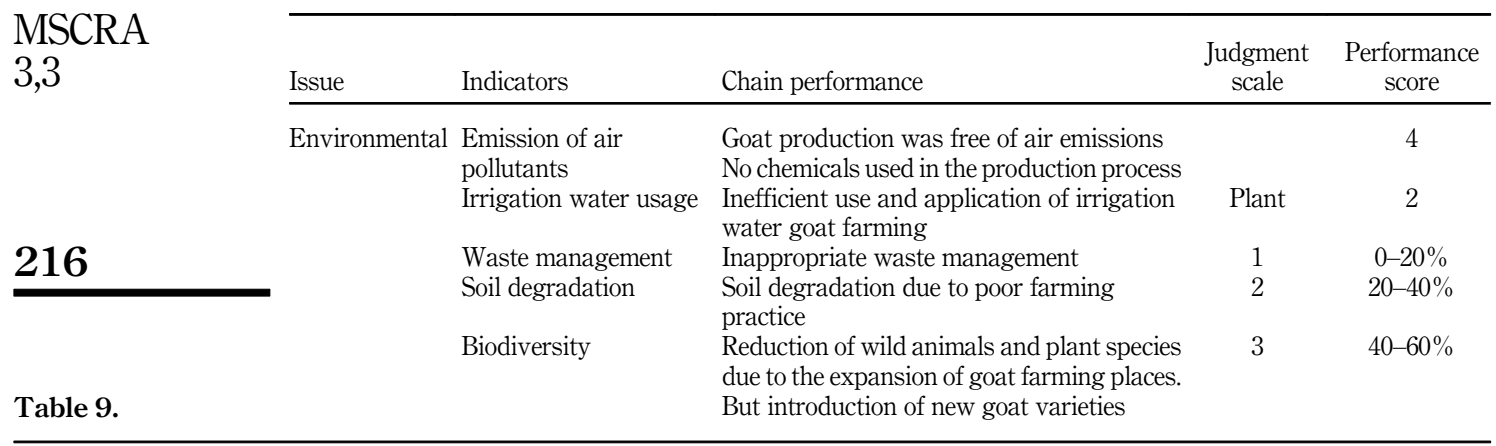

Table 10.

Sustainability performance of goat value chain in the Study areas

\begin{tabular}{ll}
\hline Factors & Performance \\
\hline Economic (profit) & Moderate score in relation to references \\
Social (people) & Moderate score in relation to references \\
Environment (Earth) & Moderate score in relation to references \\
\hline
\end{tabular}

market access and profitability. Value chains of goat and goat-products and their goal are essential to develop idea on learning, investment, market access, sales assurance and quality. Checking commission agents through strong monitoring from the concerned desk can bring some benefits for the farmers to receive proper and fair prices of their products. All actors or stakeholders of the value chains should concentrate on competitiveness and productivity and look for and exploit multiple ways to add value once initial success has been attained with a single deal. Ensuring sustainability within the value chains are key important features to cater for the challenges and changing demands of age. Strong private sector alliance along with public-private ventures can bring a sustainable agriculture value chain development in these most vulnerable coastal communities in Bangladesh. Strengthening the weak financial structure, focus more on formal financial systems, reducing power imbalances in the governance structures and low political intervention in community level organizations, and resolving socio-cultural and environmental concerns are the major concerns on development of value chains in developing countries. Apparently, guarantee for good governance, checking illegal and unregulated market contexts, proper farming techniques are some paramount important issues for the sustainable management of livelihood, yield, income and development of goat farming practices in the target areas.

The authors recommended for some approaches should be taken immediately for sustainable value chain for domestic livestock production and marketing in the coastal area for increase the income generating activities, self-employment and adaptation of climate change through improvement of the value chain with new interventions (Table 12).

Through justification of inferential and experiential study, the authors have recommended a specialized model for the abolition of poverty during the value chain sustainability in responses to climate change in the sample areas, established by the following figure. This is verified value chain sustainability with the concept of 3BL theme like Economic performance, Social performance and Environmental performance for eradication of the poverty of climate victims of coastal Bangladesh. The model suggested that performance of ESE performances, as sustainability possibly will play function in supporting of poverty eradication from the society of coastal inhabitants of Bangladesh (Figure 12). 


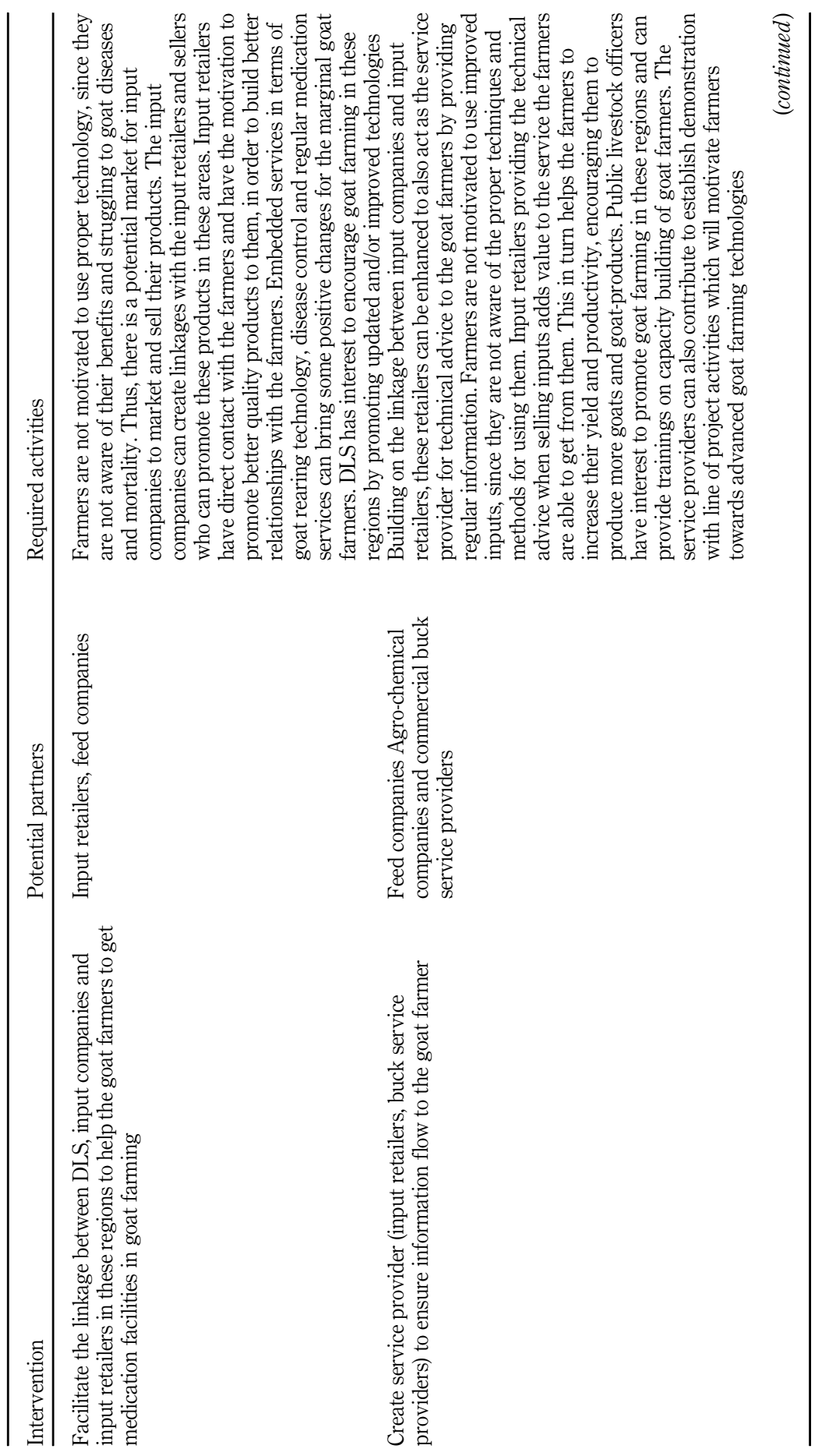

Sustainable

value chain approach for livestock

217

Table 11.

Sustainable value chain approach for goat farming and marketing 
MSCRA

3,3

218

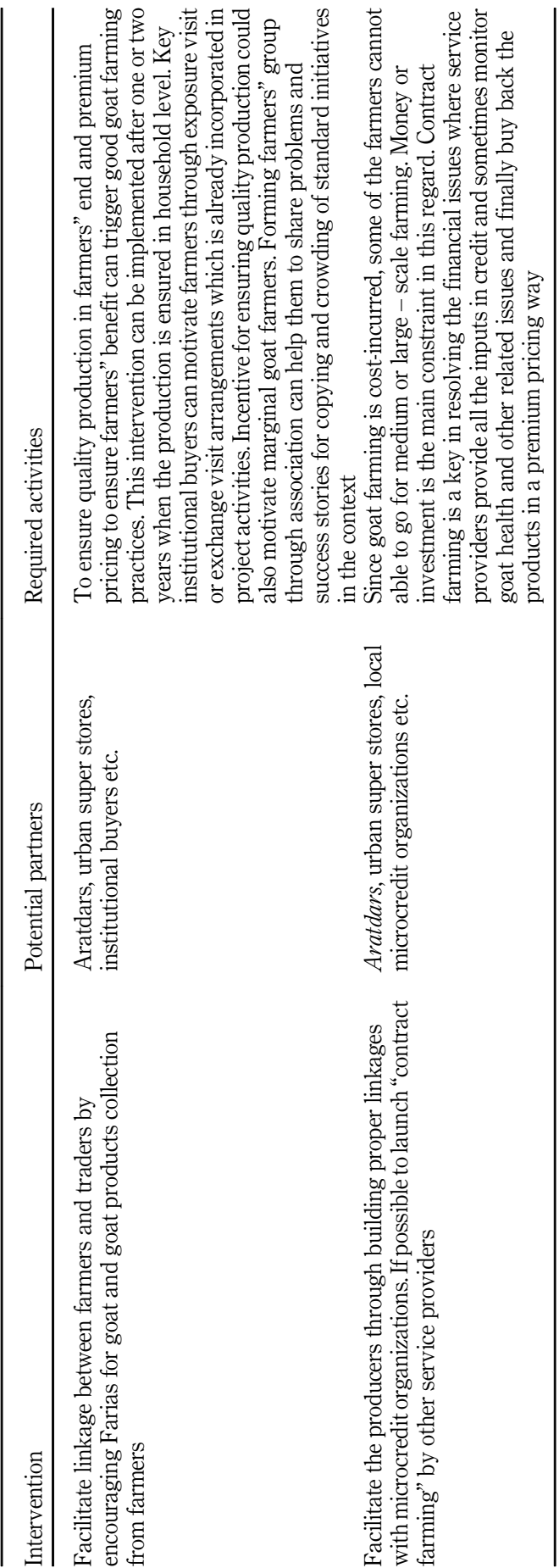

Table 11.

缕 


\begin{tabular}{|c|c|c|c|c|c|c|}
\hline Constraint & Intervention & Output & Outcome & Impact & $\begin{array}{l}\text { Potential } \\
\text { partner }\end{array}$ & $\begin{array}{l}\text { Sustainable } \\
\text { value chain }\end{array}$ \\
\hline \multirow[t]{2}{*}{$\begin{array}{l}\text { Goat farmers } \\
\text { are struggling } \\
\text { to get rid of } \\
\text { diseases and } \\
\text { mortality }\end{array}$} & \multirow{2}{*}{$\begin{array}{l}\text { Facilitate the } \\
\text { linkage between } \\
\text { DLS, input } \\
\text { companies and } \\
\text { input retailers in } \\
\text { these regions to } \\
\text { help the farmers to } \\
\text { get medication } \\
\text { facilities }\end{array}$} & \multirow{2}{*}{$\begin{array}{l}\text { Public and } \\
\text { private service } \\
\text { providers will } \\
\text { be able to } \\
\text { provide } \\
\text { embedded } \\
\text { technical } \\
\text { services to the } \\
\text { marginal } \\
\text { households in } \\
\text { goat farming }\end{array}$} & \multirow[t]{2}{*}{$\begin{array}{l}\text { Farmers are able } \\
\text { to avail quality } \\
\text { medical facilities } \\
\text { for goat rearing }\end{array}$} & \multirow[t]{2}{*}{$\begin{array}{l}\text { Farmers are } \\
\text { able to have } \\
\text { higher yield } \\
\text { by at least } \\
20-50 \%\end{array}$} & \multirow[t]{2}{*}{$\begin{array}{l}\text { Input retailers, } \\
\text { feed companies }\end{array}$} & $\begin{array}{r}\text { approach for } \\
\text { livestock }\end{array}$ \\
\hline & & & & & & \\
\hline \multirow{2}{*}{$\begin{array}{l}\text { Goat farmers } \\
\text { follow } \\
\text { traditional } \\
\text { farming } \\
\text { practices they } \\
\text { do not have } \\
\text { access to } \\
\text { information on } \\
\text { improved } \\
\text { practice }\end{array}$} & $\begin{array}{l}\text { Create service } \\
\text { provider (input } \\
\text { retailers, buck } \\
\text { service providers) } \\
\text { To ensure } \\
\text { information flow to } \\
\text { the goat farmer }\end{array}$ & $\begin{array}{l}\text { Service } \\
\text { providers are } \\
\text { providing } \\
\text { information on } \\
\text { better goat } \\
\text { farming } \\
\text { practices to the } \\
\text { farmers }\end{array}$ & $\begin{array}{l}\text { Farmers are using } \\
\text { better farming } \\
\text { techniques }\end{array}$ & $\begin{array}{l}\text { Goat farmers } \\
\text { are able to } \\
\text { have higher } \\
\text { yield } 20-50 \%\end{array}$ & $\begin{array}{l}\text { Feed } \\
\text { companies } \\
\text { Agro-chemical } \\
\text { companies and } \\
\text { commercial } \\
\text { buck service } \\
\text { providers }\end{array}$ & \\
\hline & $\begin{array}{l}\text { Set up } \\
\text { demonstrations to } \\
\text { showcase better } \\
\text { farming practices }\end{array}$ & $\begin{array}{l}\text { Farmers are } \\
\text { able to see and } \\
\text { learn about } \\
\text { better goat } \\
\text { farming } \\
\text { practices }\end{array}$ & & & $\begin{array}{l}\text { Feed } \\
\text { companies } \\
\text { Agro- chemical } \\
\text { companies and } \\
\text { commercial } \\
\text { buck service } \\
\text { providers }\end{array}$ & \\
\hline $\begin{array}{l}\text { Goat traders are } \\
\text { not sourcing } \\
\text { from these } \\
\text { regions }\end{array}$ & $\begin{array}{l}\text { Facilitate linkage } \\
\text { between farmers } \\
\text { and traders by } \\
\text { encouraging Farias } \\
\text { for goat and goat } \\
\text { products collection } \\
\text { from farmers }\end{array}$ & $\begin{array}{l}\text { Farmers are } \\
\text { producing goat } \\
\text { and goat } \\
\text { products in bulk }\end{array}$ & $\begin{array}{l}\text { Traders are } \\
\text { actively sourcing } \\
\text { goat and goat } \\
\text { products from } \\
\text { these regions }\end{array}$ & $\begin{array}{l}\text { Farmers are } \\
\text { motivated and } \\
\text { growing more } \\
\text { goats and goat } \\
\text { products }\end{array}$ & $\begin{array}{l}\text { Aratdars, } \\
\text { urban super } \\
\text { stores, } \\
\text { institutional } \\
\text { buyers etc. }\end{array}$ & \\
\hline $\begin{array}{l}\text { Farmers are not } \\
\text { getting access } \\
\text { to finance }\end{array}$ & $\begin{array}{l}\text { Facilitate the } \\
\text { producers through } \\
\text { building proper } \\
\text { linkages with } \\
\text { microcredit } \\
\text { organizations. If } \\
\text { possible to launch } \\
\text { "Contract Farming" } \\
\text { by other service } \\
\text { providers }\end{array}$ & $\begin{array}{l}\text { Farmers are } \\
\text { getting loans } \\
\text { and credits to } \\
\text { ensure their } \\
\text { production cost } \\
\text { during farming } \\
\text { season. } \\
\text { Contractors are } \\
\text { providing all the } \\
\text { inputs in credit }\end{array}$ & $\begin{array}{l}\text { Microcredit } \\
\text { organizations are } \\
\text { getting their } \\
\text { marginal profit or } \\
\text { contractors are } \\
\text { getting benefit in } \\
\text { terms of } \\
\text { procuring quality } \\
\text { products }\end{array}$ & $\begin{array}{l}\text { Farmers are } \\
\text { capable to } \\
\text { manage } \\
\text { production } \\
\text { cost to cope up } \\
\text { with advanced } \\
\text { farming } \\
\text { system }\end{array}$ & $\begin{array}{l}\text { Microcredit or } \\
\text { cooperative } \\
\text { and NGOs, } \\
\text { service } \\
\text { providers }\end{array}$ & $\begin{array}{r}\text { Table 12. } \\
\text { Recommended } \\
\text { approach for } \\
\text { Improvement of the } \\
\text { Goat value chain } \\
\text { process }\end{array}$ \\
\hline
\end{tabular}

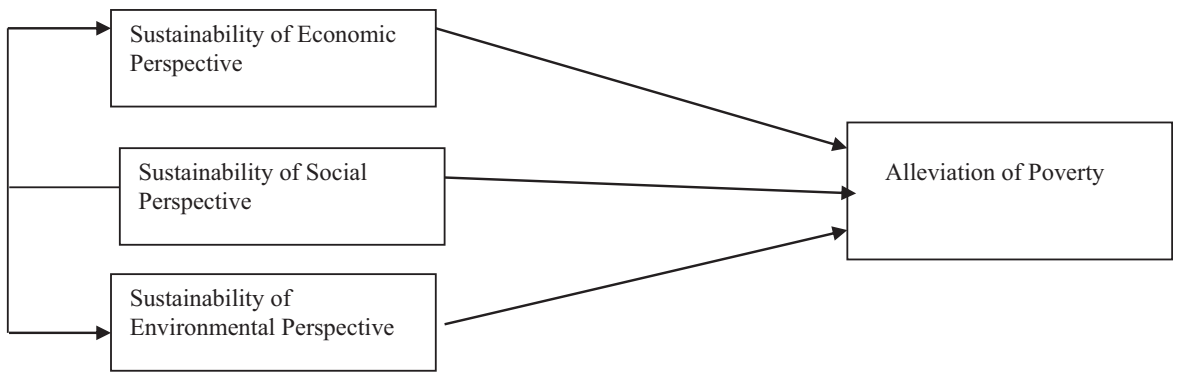

Figure 12.

Poverty Eradication Model approach in the course value chain sustainability 
MSCRA

3,3

From the finding of the study, the authors strongly recommended "Value Chain Sustainability" considerably contributed to the resolution of this social problem throughout the transfer of poverty alleviation from one aspect to another. The manuscript projected obliging the theoretical and managerial insinuation of the study with a model titled "Poverty Eradication Model through Sustainability of Value Chain". Through explanation of speculative evidence and present mathematical and qualitative assessment, the authors have been concluded sustainability of value chain approach through the process of economic, social and environmental sustainability possibly will hopeful for abolition of extreme poverty from society of coastal inhabitants of south-eastern coast of Bangladesh.

\section{References}

Alam, M.Z., Lynne, C.B., Mitra, S., Haque, M.M., Halsey, J., Rokonuzzaman, M.S., Saha, B. and Moniruzzaman, M.S. (2017), "Effect of salinity intrusion on food crops and livestock at Kalapara coastal belt in Bangladesh", Journal of Food Quality, Vol. 20 No. 3, pp. 23-45.

Barua, P. and Rahman, S.H. (2019), "Sustainable value chain approach for vegetables product", IUP Journal of Supply Chain Management, Vol. 19 No. 1, pp. 20-45.

Barua, P., Rahman, S.H. and Molla, M.H. (2017), "Sustainable adaptation for resolving climate displacement issues of south eastern islands in Bangladesh", International Journal of Climate Change Strategies and Management, Vol. 15 No. 2, pp. 60-80.

Bhowmik, N., Mia, M.M., Rahman, M.M. and Islam, S. (2014), "Preliminary Study on crossbred goats at Chittagong region of Bangladesh", Iranian Journal of Applied Animal Science, Vol. 4 No. 1, pp. 89-93.

Bonney, L., Clark, R., Collins, R. and Fearne, A. (2007), "From serendipity to sustainable competitive advantage: insights from Houston's Farm and their journey of co-innovation”, Supply Chain Management: An International Journal, Vol. 12 No. 6, pp. 395-399.

Chowdhury, K.K., Hossan, M., Quaddus, H. and Mohammed, A. (2015), "Multiple objective optimization based QFD approach for efficient resilient strategies to mitigate supply chain vulnerabilities: the case of garment industry of Bangladesh", The International Journal of Management Science, Vol. 57 No. 5, pp. 5-21.

de Bakker, F.H. and Nijhof, A. (2002), "Responsible chain management: a capability assessment framework", Business Strategy and the Environment, Vol. 11 No. 1, pp. 63-75.

DLS (2019), Livestock Production Statistical Yearbook of Bangladesh 2018-2019, Department of Livestock Services, Ministry of Fisheries and Livestock, Government of Bangladesh, Dhaka, p. 50 .

Dwivedi, A., Agrawal, D. and Madaan, J. (2019), "Sustainable manufacturing evaluation model focusing leather industries in India", Journal of Science and Technology Policy Management, Vol. 10 No. 2, pp. 319-359.

Durham, C.A., King, R.P. and Roheim, C.A. (2009), "Consumer definitions of 'locally grown' for fresh fruits and vegetables", Journal of Food Distribution Research, Vol. 40 No. 2, pp. 56-62.

FAO (2018), Sustainable Food Value Chains Knowledge Platform, Food and Agriculture Organization, Rome.

Fearne, A., Soosay, C., Stringer, R., Umberger, W., Dent, B., Camilleri, C., Henderson, D. and Mugford, A. (2009), "Sustainable value chain analysis: a case study of south Australian wine, department of primary industries and resources", International Business Journal, Vol. 10 No. 5 , pp. 50-70.

Galli, F., Bartolini, F., Brunori, G., Colombo, L., Gava, O., Grando, S. and Marescotti, A. (2015), "Sustainability assessment of food supply chains: an application to local and global bread in Italy", Agricultural and Food Economics, Vol. 3 No. 1, pp. 21-30.

Gebre, G.G. and Rik, E. (2016), "Sustainability assessment of a banana value chain: the case of Arba Minch, Ethiopia”, Journal of Agribusiness, Vol. 34 No. 2, pp. 181-190. 
Govindan, K., Wang, C. and Lim, M. (2018), "Sustainable supply chain modeling and analysis: past debate, present problems and future challenges", Resources, Conservation and Recycling, Vol. 140 No. 5, pp. $72-84$.

Hossain, M. and Deb, U. (2016), "Food security and containing escalation in prices: facts and implication for policy", Journal of Agriculture Management, Vol. 20 No. 3, pp. 150-165.

Hossain, M.S., Akhtar, A., Hossain, M.H., Choudhury, M.P. and Islam, F. (2015), "Goat husbandry practices in Southern region of Bangladesh", Journal of Bioscience and Agriculture Research, Vol. 5 No. 2, pp. 59-64.

Islam, M.S. (2003), "Perspectives of the coastal and marine fisheries of the Bay of Bengal, Bangladesh", Ocean \& Coastal Management, Vol. 46 No. 4, pp. 763-796.

Islam, N. (2014), An Introduction to Research Methodology, 3rd ed., University Press, Dhaka.

Islam, S.M.F. and Jabbar, M.A. (2010), "Consumer preferences and demand for livestock products in urban Bangladesh”, Livestock Management, Vol. 20 No. 5, pp. 50-70.

Islam, M.R., Amin, M.R., Kabir, A.K.M.A. and Ahmed, M.U. (2009), "Comparative study between semiintensive and scavenging production system on the performances of Black Bengal goat", Journal of Bangladesh Agricultural University, Vol. 7 No. 1, pp. 79-86.

Islam, M.S., Khan, M.S.I., Kader, H.A., Begum, M.R. and Asgar, M.A. (2012), "Prevalence of PPR of goat and their response to Antibiotic treatment at Mirzaganj Upazila of Patuakhali district", Journal of Environmental Science and Natural Resources, Vol. 5 No. 2, pp. 181-184.

Kaplinsky, R. and Morris, M. (2000), A Handbook for Value Chain Research, Institute of Development Studies, UK.

Lihua, C., Liying, W. and Yingjie, L. (2019), "Auction models with resource pooling in modern supply chain management", Modern Supply Chain Research and Applications, Vol. 1 No. 2, pp. $120-134$.

Lim-Camacho, L., Alistair, J.H., Rodrigo, H.B., Anna, F.B., Fleming, S., Stewart, F., Bridget, S., Green, A.N., Peggy, S., Schrobback, O. and Ingrid, V.P. (2015), "Facing the wave of change: stakeholder perspectives on climate adaptation for Australian seafood supply chains", Regional Environmental Change, Vol. 15 No. 4, pp. 595-606.

Lim-Camacho, L., Ariyawardana, A., Crimp, S.J., Somogyi, S., Ridoutt, B. and Howden, S.M. (2016), "Climate adaptation of food value chains: the implications of varying consumer acceptance", Regional Environmental Change, Vol. 17 No. 2, pp. 93-103.

Lufei, H., Liwen, M. and Wencheng, W. (2020), "Green closed-loop supply chain network design considering cost control and CO2 emission”, Modern Supply Chain Research and Applications, Vol. 2 No. 1, pp. $42-59$.

MoFL (2019), Livestock Production Statistical Yearbook of Bangladesh 2019-2020, Ministry of Fisheries and Livestock, Government of Bangladesh, Dhaka, p. 80.

Mohamadou, F. (2013), "Situation analysis of small ruminants value chain in Ethiopia", International Journal of Management, Vol. 20 No. 5, pp. 90-98.

Moktadir, M.A., Dwivedi, A., Ali, S.M., Paul, S.K., Kabir, G. and Madaan, J. (2019), "Antecedents for greening the workforce: implications for green human resource management", International Journal of Manpower, Vol. 41 No. 7, pp. 1135-1153.

Moktadir, M.A., Dwivedi, A., Rahman, A., Chiappetta Jabbour, C.J., Paul, S.K., Sultana, R. and Madaan, J. (2020), "An investigation of key performance indicators for operational excellence towards sustainability in the leather products industry", Business Strategy and the Environment, Vol. 29 No. 8, pp. 3331-3351.

Moreno, C.A.P. and Salgado, O. (2012), "Sustainability indicators along the coffee value chain: a comparative study between Mexican and Colombian retail", Journal of Management, Vol. 50 No. 8 , pp. 65-75.

Neven, D. (2014), "Developing sustainable food value chains-guiding principles", Journal of Agriculture Management, Vol. 20 No. 5, pp. 56-65. 
MSCRA 3,3

\section{2}

Porter, M.E. (1985), The Competitive Advantage: Creating and Sustaining Superior Performance, Free Press, New York.

Porter, M. and Kramer, M. (2006), "Strategy and society: the link between competitive advantage and corporate social responsibility", Harvard Business Review, Vol. 84 No. 12, pp. 78-92.

Rahman, S., Begum, I.R. and Alam, M.J. (2018), "Livestock in Bangladesh: distribution, growth, performance and potential", Livestock Research for Rural Development, Vol. 30 No. 5 , pp. $45-65$.

Sarker, S.C.F., Islam, M., Akteruzzaman, A.M.O., Ibrahim, I., Baltenweck, N. and Bhuiyan, A.K.F. (2014), "Impact of buck parks on improvement of Black Bengal goats in Rural Bangladesh", Journal of Livestock Management, Vol. 5 No. 3, pp. 50-65.

Siddiky, N.A. (2017), Sustainable Goat Farming for Livelihood Improvement in South Asia, SAARC Agriculture Centre, Dhaka.

Singh, U.S. and Mishra, U.S. (2013), "Vegetable supply chain: a conceptual study", Food Science and Quality Management, Vol. 15 No. 3, pp. 45-50.

Taylor, D.H. (2005), "Value Chain Analysis: an approach to supply chain improvement in agri-food chains", International Journal of Physical Distribution and Logistics Management, Vol. 35 No. 10, pp. 744-761.

Trienekens, J.H. (2011), “Agricultural value chains in developing countries: a framework for analysis”, International Food and Agribusiness Management Review, Vol. 14 No. 2, pp. 51-82.

USAID (2012), Facilitating Systemic Change in Value Chains: Lessons Learned for Strengthening Country Systems, United States for International Development, p. 12.

\section{Further reading}

Begum, I.A., Alam, M.J., Buysse, J., Frija, A. and Van Huylenbroeck, G. (2011), “A comparative efficiency analysis of poultry farming systems in Bangladesh: a Data Envelopment Analysis approach", Applied Economics, Vol. 44 No. 2, pp. 3737-3747.

IMF (2005), Bangladesh Poverty Reduction Strategy Paper, International Monetary Fund Country Report No. 04/410, Washington, DC. 


\section{Appendix}

Questionnaire used for primary data collection in beneficiary level

S.L. No

Date of Interview:

Area : District Upazila/Thana.

Union/Ward
Sustainable value chain approach for livestock

A. Socio-Economic Condition of the Respondent

1. Name

2. Age

3. Education: 1. Illiterate, 2. Can sign only, 3. Class I-IV, 4. PSC 5. JSC 6. SSC 7. HSC 8. Honours/Degree 9. Post Graduation 10. Others (Specify)

4. Gender: 1. Male 2. Female

5. Occupation and monthly income : 1. Agriculture, 2. Fishermen 3. Fish/Shrimp Collectors 4. Day labour 5. Rickshaw/Van Puller, 6. CNG/ Transport driver/Assistant 7. Garments worker 8. Salt Farmer 9. Building worker 10. Small traders 11. Dry Fish processing labour 12. Boat/ Launch driver 13. Housewife 14. Student 15. Unemployed 16. Others (Specify)

6. Monthly Income: 1. 1000/- 3,000/- 2. 3,001/--5,000/- 3. 5,0001/--8,000/4. $8,001 /--10,000 /-5$. More than $10000 /-$

7. Types of House : 1. Shanty House 2. Kuncha (Clay roof/ Thatch) 3. Kuncha (Clay Wall/Tin) 4. Semi-Pucca 5. Pucca, 6. Others, specify

9. Description of the household assests

\begin{tabular}{|l|l|l|l|}
\hline Name of Assests & Numbers & Tentative Price (BDT) & Total Amount (BDT) \\
\hline Chicken & & & \\
\hline Duck & & & \\
\hline Goat & & & \\
\hline Cow & & & \\
\hline Sheep & & & \\
\hline Buffelow & & & \\
\hline Mobile & & & \\
\hline Freeze & & & \\
\hline TV/Radio & & & \\
\hline Rickshaw/Van/CNG/ & & & \\
\hline Tructor & & & \\
\hline Souse & & & \\
\hline
\end{tabular}




\section{MSCRA}

3,3

\section{4}

10. Numbers of earning members in the family.

11. How many people involved for goat rearing? Father .hr, son hr, daughter..............hr , others.............hr

12. Are you taking wages from goat rearing? Days; BDT

13. How many days goat rearing continue? year/months

14. Collection of goat child..........production in own house/sellers/Govt. office/Non-Govt. farming/ others

15. Selling of produced goats .......from house/local market/others place

16. Any formal training of goat rearing? Yes/No If Yes, where? -------Govt. hospital/NGO

17. Found advice/ Cooperation from Govt. officers? Yes/No If Yes, what kind of support?

18. Are you participating in Upazila Agricutlure Fair? .Yes/No

19. Any vaccine camp regularly conduct in your area? Yes/No

20. Are you practing goat rearing through perch technology Yes/No

21. Are you familiar to cultivate grass with hydrophic system. Yes/No

22. Is the easy Access to buck service in goat farming. Yes/No

23. Are you know about community based organization (CBO)/ association among goat farmers Yes/No

If yes, please mentioned the name of the organization.

24. Are you found Microfinance/Credits for goat farming? ----- Yes/No If Yes, which NGO.

25 . Any way of profit by goat rearing? Yes/ No If Yes, whcih categories......sell goat milk/Biogas plant/ compost fertlizer/ Others

26. Are the accessbility of input services (Food, medicine and others) required for goat rearing is easy in local market or other sources....... Yes/No

27. Do you found facilities for marketing of goat proudcts (meat, milk) after production...... Yes/No

If Yes, what type of facilities. 
28. Do you have any knowledge of Goat Development Policy and Feed Act.......Yes/No

If Yes, what type of Knowledge

29. Please mentioned the problems you are facing during goat rearing? a)

..b).

30. How many goats sell in last 1 year?

31 . How many goats died in last 1 year?

32. Who provide the treatment for disease affected goats........local doctor/Hospital/ Kabiraj/ What are the quality of treatment

33. Mentioned the Income from goat rearing in previous year

\begin{tabular}{|l|l|l|l|}
\hline Expenditure issues & Costing (BDT) & Income issues & Incme(BDT) \\
\hline Goat Purchase & & Goat Selling & \\
\hline Purchase Food & & Selling Meat & \\
\hline Purchase/cultivate grass & & Others & \\
\hline Medicine/Vaccine/treatment & & & \\
\hline Labour costing & & & \\
\hline Others & & & \\
\hline Total & & & \\
\hline
\end{tabular}

34. Yearly income through goat rearing-------BDT

35 . Yearly income of the family excluding goat rearing..... BDT

36. Are you continue goat rearing Yes/No

Comments of Interviewer
Sustainable value chain approach for livestock

\section{Thank You So Much}

\section{Corresponding author}

Prabal Barua can be contacted at: prabalims@gmail.com

For instructions on how to order reprints of this article, please visit our website:

www.emeraldgrouppublishing.com/licensing/reprints.htm

Or contact us for further details: permissions@emeraldinsight.com 